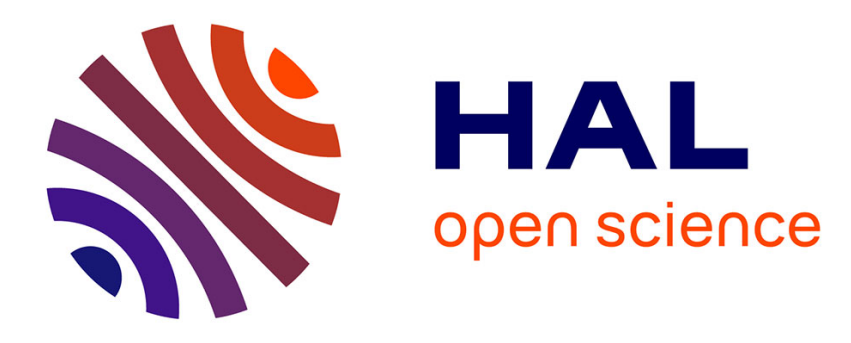

\title{
No thinning of the lithosphere beneath northern part of the Cook-Austral volcanic chains
}

\author{
C Adam, A Bonneville
}

\section{To cite this version:}

C Adam, A Bonneville. No thinning of the lithosphere beneath northern part of the Cook-Austral volcanic chains. Journal of Geophysical Research: Solid Earth, 2008, 10.1029/2007JB005313 . insu01288730

\section{HAL Id: insu-01288730 \\ https://hal-insu.archives-ouvertes.fr/insu-01288730}

Submitted on 15 Mar 2016

HAL is a multi-disciplinary open access archive for the deposit and dissemination of scientific research documents, whether they are published or not. The documents may come from teaching and research institutions in France or abroad, or from public or private research centers.
L'archive ouverte pluridisciplinaire HAL, est destinée au dépôt et à la diffusion de documents scientifiques de niveau recherche, publiés ou non, émanant des établissements d'enseignement et de recherche français ou étrangers, des laboratoires publics ou privés. 


\title{
No thinning of the lithosphere beneath northern part of the Cook-Austral volcanic chains
}

\author{
C. Adam $^{1}$ and A. Bonneville ${ }^{2}$ \\ Received 7 August 2007; revised 4 April 2008; accepted 10 July 2008; published 18 October 2008.
}

[1] The Cook-Austral volcanic chains are situated in the South Pacific. They are composed of several volcanic chains and isolated volcanoes corresponding to distinct events from $55 \mathrm{Ma}$ to present time. The tectonic history of the volcanoes emplacement is quite complex. It involves the activity of at least three hot spots, and sometimes several volcanic stages coexist on the same volcano. The purpose of this study is to bring new information on the loading history of the northern part of the Austral chain by studying the variation of the elastic thickness of the lithosphere. We have used the high-quality data acquired during the ZEPOLYF2 cruise which conducted in July 1999, a multibeam survey of this area, and we got several new ages on seamounts. In this region where several volcanic stages overlap, the simple elastic model applied on the present-day bathymetry is not appropriate. We then reconstructed the loading history of each volcano or group of volcanoes using information provided by the radiometric ages and chemical signature of the volcanic stages or the volcanoes morphology. We show that the lithosphere is characterized by normal elastic thickness if one correctly isolates the different volcanic stages occurring on this area. The abnormally low values of the effective elastic thickness obtained previously over this area may be explained either by not taking into account the overlapping volcanism or by poor quality of the geophysical data used for the determination.

Citation: Adam, C., and A. Bonneville (2008), No thinning of the lithosphere beneath northern part of the Cook-Austral volcanic chains, J. Geophys. Res., 113, B10104, doi:10.1029/2007JB005313.

\section{Geological Context}

\subsection{The Archipelago}

[2] The Cook-Austral volcanic chains are located on the southern part of the Pacific Plate, in a region of anomalous shallow seafloor known as the South Pacific Superswell [McNutt and Fischer, 1987].

[3] The Cook-Austral chains extend from the island of Aitutaki $\left(140^{\circ} \mathrm{W}, 29^{\circ} \mathrm{S}\right)$ to the active submarine volcano Macdonald $\left(160^{\circ} \mathrm{W}, 19^{\circ} \mathrm{S}\right)$ in a band more than $2200 \mathrm{~km}$ long and $240 \mathrm{~km}$ wide, oriented $\mathrm{N} 115^{\circ} \mathrm{E}$ (Figure 1). The chains are composed of several dozens of seamounts and of 11 islands and 2 atolls. Although oriented roughly in the direction of present Pacific plate motion $\left(11 \mathrm{~cm} \mathrm{a}^{-1}\right.$ along the $\mathrm{N} 115^{\circ}$ direction), the spatial and temporal pattern of both the aerial and submarine volcanoes is rather complex. The age of the oceanic crust along the chain ranges from about 39 to 84 Ma to previous researchers [Mayes et al., 1990].

\footnotetext{
${ }^{1}$ Institute for Research on Earth Evolution, Japan Agency for MarineEarth Science and Technology, Yokosuka, Japan.

${ }^{2}$ Laboratoire de Géosciences Marines, Institut de Physique du Globe de Paris, CNRS, Paris, France.

Copyright 2008 by the American Geophysical Union. 0148-0227/08/2007JB005313\$09.00
}

[4] The particular geometry and morphology of the chains suggested two distinct but parallel alignments. McNutt et al. [1997] determined the existence of two additional chains of volcanoes (Taukina and Ngatemato) near the active Macdonald seamount at the southeast end of the chain, 20-34 Ma older than the Macdonald volcanism. Both recent and old ages [Turner and Jarrard, 1982; Barsczus et al., 1994] recorded on Aitutaki, and Rurutu islands from basaltic samples require the existence of two other hot spots (Rarotonga and Rurutu). Bonneville et al. [2002] attributed the most recent volcanic stage of Rurutu to the Arago Seamount, a very shallow seamount located $120 \mathrm{~km}$ east-southward of Rurutu and sampled during the ZEPOLYF2 cruise. Up to 6 distinct hot spot tracks have been identified so far [Bonneville et al., 2006]: from northwest to southeast, Rarotonga, "old" and "young" Rurutu, Macdonald, Taukina and Ngatemato of which three are probably still active: Rarotonga and Macdonald (which are named after the emplacement of the active volcanism) and young Rurutu, now active at the Arago Seamount volcano (Figure 1).

[5] These three active tracks are characterized by coherent age progression and distinct geochemical signatures. Concerning Rarotonga, neither the observed age (1 Ma), nor isotopic analysis allows us to connect it with the above mentioned tracks. It seems to be an isolated hot spot. The same observations can be made for Aitutaki, an atoll situated less than $250 \mathrm{~km}$ north of Rarotonga and dated at 


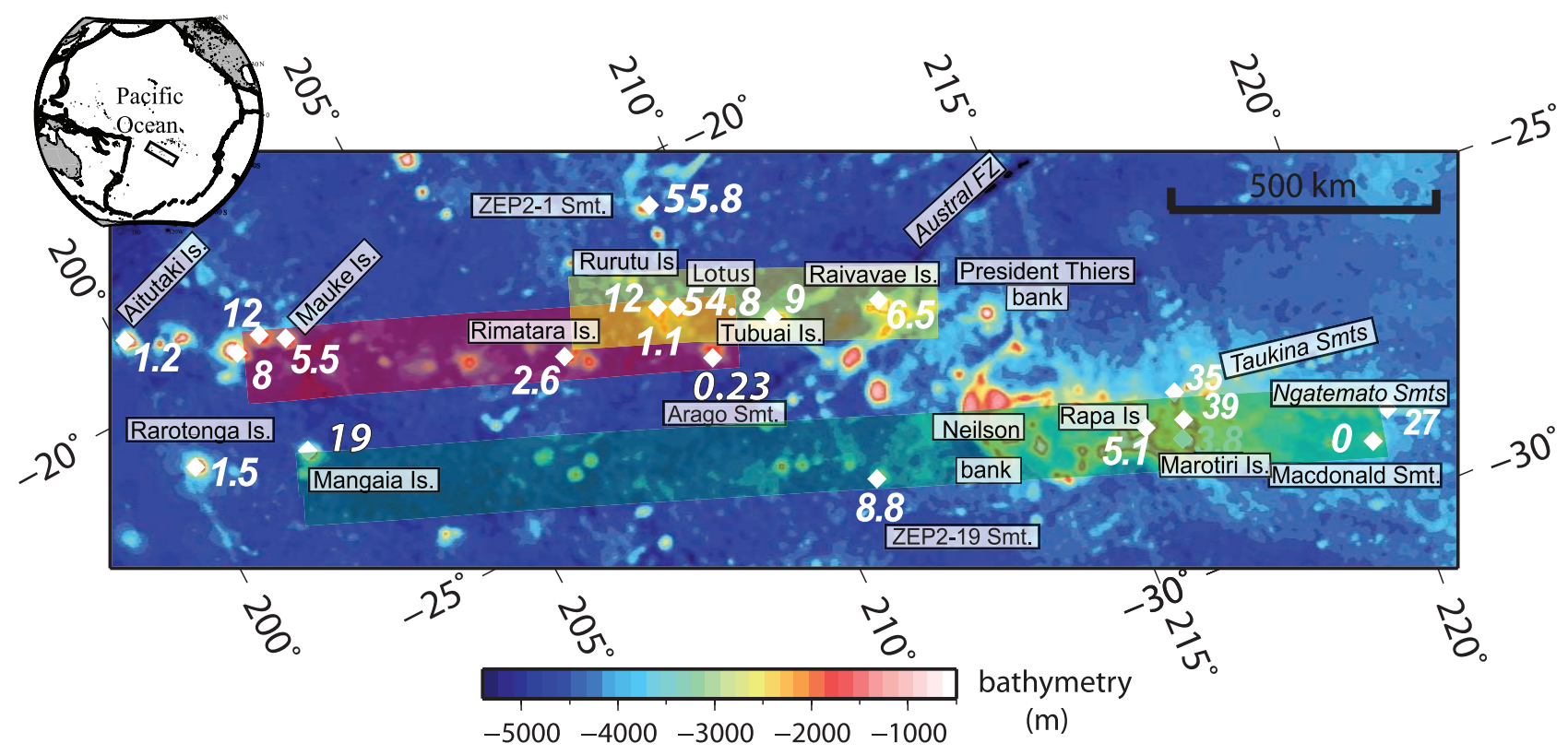

Figure 1. Bathymetry of the Cook-Austral volcanic chain, projected along the direction of the present Pacific plate motion $\left(\mathrm{N} 115^{\circ}\right)$. The green, yellow, and red ribbons represent the Macdonald and the old and young Rurutu tracks, respectively, as defined in the text. Note that volcanoes are often not located exactly on the middle of a track, which could indicates the importance of lithospheric control rather than a change in the location of the magmatic source. The volcanism ages are in million years.

1.2 Ma [Turner and Jarrard, 1982]. The young and old Rurutu tracks overlap each other. Sometimes this occurs on the same volcano, as in Rurutu and Arago. These two tracks occur in the same area as an older phase of volcanism which created the Lotus guyot (54.8 Ma) and the ZEP2-1 seamount $(55.8 \mathrm{Ma})$. To the south, the volcanism which is now active at the Macdonald, and which is responsible for the more recent stage at Marotiri (4 Ma) and ZEP2-19 (8.9 Ma) and for the creation of Rapa (5.1 Ma) and Mangaia (20 Ma), also overlaps an older stage which built $\mathrm{Ra}$ (29 Ma), Marotiri (32 Ma), ZEP2-19 (20-33 Ma) and the Neilson Bank (40 Ma).

[6] The existence of several stages of loading on the same volcanic edifice seems to be the rule rather than the exception in this region. Therefore, we need to consider this complex history in computing the apparent elastic thickness $\left(T_{e}\right)$ of the lithosphere, a parameter used in most the thermomechanical models of the plate, which as a result has important consequences in the interpretation of the volcanism. In this paper, we are going to revisit the estimates of $T_{e}$ the under the northeastern part of the Cook-Austral chains using a new set of bathymetry and gravity data and absolute ages.

\section{Elastic Thickness of the Lithosphere \\ 2.1. Definition}

[7] In response to volcanic loads, the oceanic lithosphere acts as a thin elastic plate overlying an inviscid fluid [Watts et al., 1980], (see Figure 2). The amplitude of the deflection depends on both the size of the volcanic load and the effective flexural rigidity of the thin elastic plate [Watts et al., 1975]. The flexural rigidity of the plate $D$ is linked to the elastic lithospheric thickness $T_{e}$ by

$$
D=\frac{E T_{e}^{3}}{12\left(1-\nu^{2}\right)}
$$

where $E$ is the Young's modulus $\left(E=8 \times 10^{10} \mathrm{~N} \mathrm{~m}^{-1}\right)$ and $\nu$ is the Poisson's ratio $(v=0.25)$.

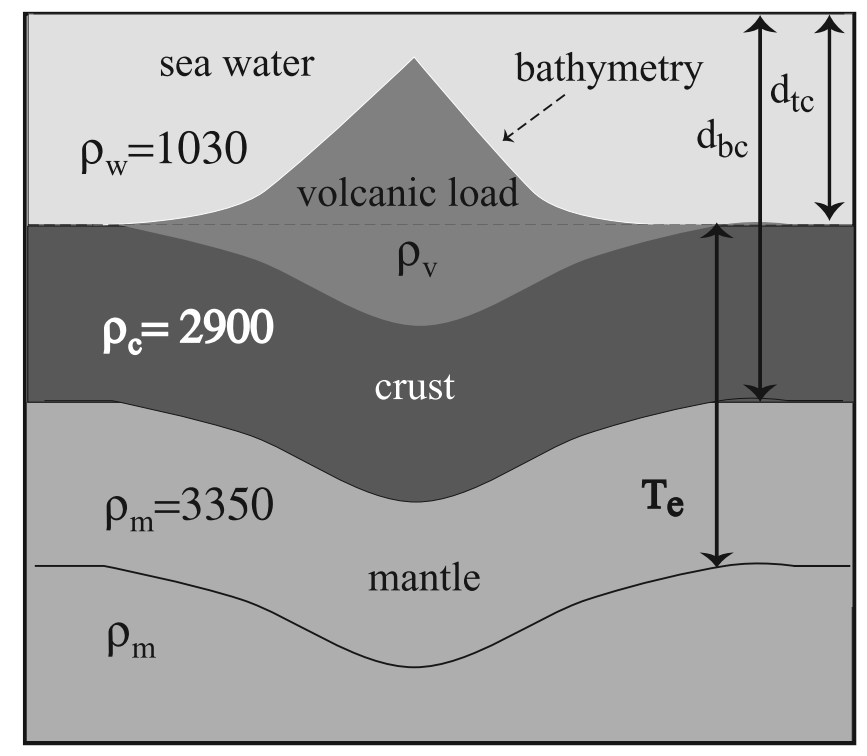

Figure 2. Model of regional compensation of a volcanic load. The values of the densities used in this study are given in $\mathrm{kg} \mathrm{m}^{-3}$. 


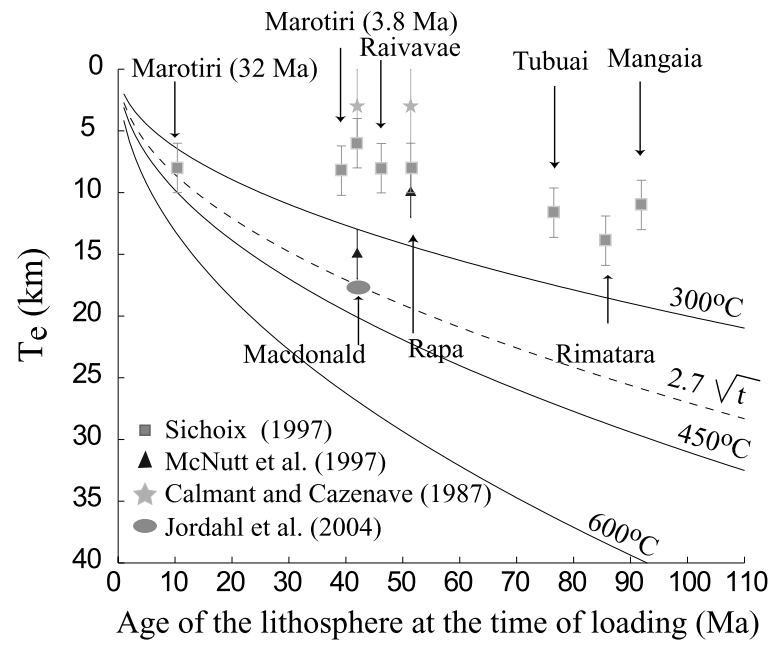

Figure 3. Synthesis of the elastic thickness available for the Cook-Austral volcanic chain before the present study. The elastic thickness is represented as a function of the age of the lithosphere at the time of loading. We have also reported the theoretical curves (the 300,450 , and $600^{\circ} \mathrm{C}$ isotherms) as well as the empirical curve of Calmant and Cazenave [1987] $(2.7 \sqrt{t})$.

[8] The elastic thickness corresponds to the upper part of the lithosphere and depends mainly on the temperature and hence on the age of the lithosphere at the time of loading [Watts, 1978; Cazenave et al., 1980]. The elastic thickness increases with the age of the plate according to a square root law. A comparison with the cooling plate model of Parsons and Sclater [1977] has led Watts [1978] to associate $T_{e}$ to the $450 \pm 150^{\circ} \mathrm{C}$ oceanic isotherm which corresponds to the transition from ductile to elastic behavior on long timescales. In a classic study, Watts [1978] has gathered several determinations of the elastic thickness in various tectonic contexts. McNutt [1984] introduced the concept of the "effective thermal age," which corresponds to the thermal age at the time of loading. It can be younger than the lithospheric age if the plate has been reheated, which is common for regions of intraplate volcanism. Calmant and Cazenave [1986] and Young and Hill [1986] also invoke this concept to explain rigidity anomalies obtained below the Cook, Austral, and Society Islands, and below the Cape Verde rise. The effective flexural rigidity only approximates the rheological response of the lithosphere which could be more complex than that of a perfectly elastic model. The model always leads to an overestimate of the stress for a given load, whereas any other model (e.g., elastic with a discontinuity, viscoelastic, layered viscoelastic or elastoplastic) will give reduced values for the implied stress [McNutt, 1980]. The elastic thickness is, however, a good proxy to describe the thermomechanical behavior of the oceanic lithosphere at the geological timescales.

\subsection{Previous Determination of $T_{e}$ Beneath the Cook-Austral Chain}

[9] Previous studies over this region [Calmant and Cazenave, 1986; Sichoix, 1997] reported abnormally low values of the elastic thickness that have long been attributed to the south Pacific Superswell (see Figure 3). This unusually shallow region is characterized by numerous geophysical anomalies (negative seismic velocities which indicate a hotter mantle beneath this region, large wavelength geoid low, volcanism concentration). These observations may be explained by the upwelling of a superplume [McNutt and Fischer, 1987; McNutt, 1998]. But, most of the abnormally low values of the elastic thickness have then been explained by the poor quality of the bathymetry and gravity data used in the earliest studies of the lithosphere deformation. Thus, low values of the elastic thickness are found from single-beam bathymetry [McNutt and Menard, 1978; Cazenave et al., 1980; Calmant and Cazenave, 1987], while from multibeam bathymetry, normal values of the elastic thickness are found for the Society and the Marquesas islands [Filmer et al., 1993; Sichoix, 1997]. The Cook-Austral chain is the only alignment under which the lithosphere seems abnormally thin. Note that in this region, few multibeam data were available, except at the southeastern extremity over the Taukina, Ngatemato, and the active part of the Macdonald chains where recent studies [McNutt et al., 1997; Jordahl et al., 2004] report a normal thickness of the lithosphere. In the continuation of these fruitful works, we are studying in the present paper the lithosphere state of the northern part of the Austral islands from new and good quality data.

\subsection{Bathymetry and Gravity Data}

[10] In summer 1999, the ZEPOLYF2 cruise [Bonneville, 2001] surveyed the northern part of the Austral islands. Its first objective was to completely map with a multibeam instrument all the seamounts located by satellite altimetry in this area; $100,000 \mathrm{~km}^{2}$ were thus covered, and more than $10,000 \mathrm{~km}$ of geophysical profiles were gathered, including $5000 \mathrm{~km}$ of single-channel seismic reflection data. A complete sampling of the 30 seamounts was also planned and 24 successful dredges were collected [Bonneville et al., 2006]. Note that most of the seamounts were unnamed and have been numbered (ZEP2-1 to ZEP2-22).

[11] In our study, we are using the bathymetry and gravity data collected during this survey (data coverage is displayed in Figure 4) to compute the elastic thickness under the volcanic loads. For each volcano we create a bathymetry grid by interpolating the data with the "block median" and "surface" GMT functions [Wessel and Smith, 1991]. The mesh step is constant for each grid and depends on the size and the shape of the studied volcano: the smaller and sharper the edifice, the finer the grid. Outside of the multibeam covering, we impose a constant regional depth.

\subsection{Determination of $T_{e}$}

[12] $T_{e}$ is estimated from the deflection of the lithosphere under a volcanic load, either island or seamount. We use a spectral approach to solve the classical equation governing the deformation $\mathrm{w}(\mathrm{x})$ (positive downward) of an elastic layer under loading. In the wave number domain, the 2-D Fourier transform of the flexure $W(k)$ is given by

$$
W(k)=\left(\rho_{v}-\rho_{w}\right)\left[\frac{(2 \pi|k|)^{4} D+\left(\rho_{m}-\rho_{v}\right) g}{g}\right]^{-1} H(k)
$$

where $H(k)$ is the Fourier transform of the topography; $\rho_{v}, \rho_{w}$, and $\rho_{m}$ are the densities of the volcanic load, 


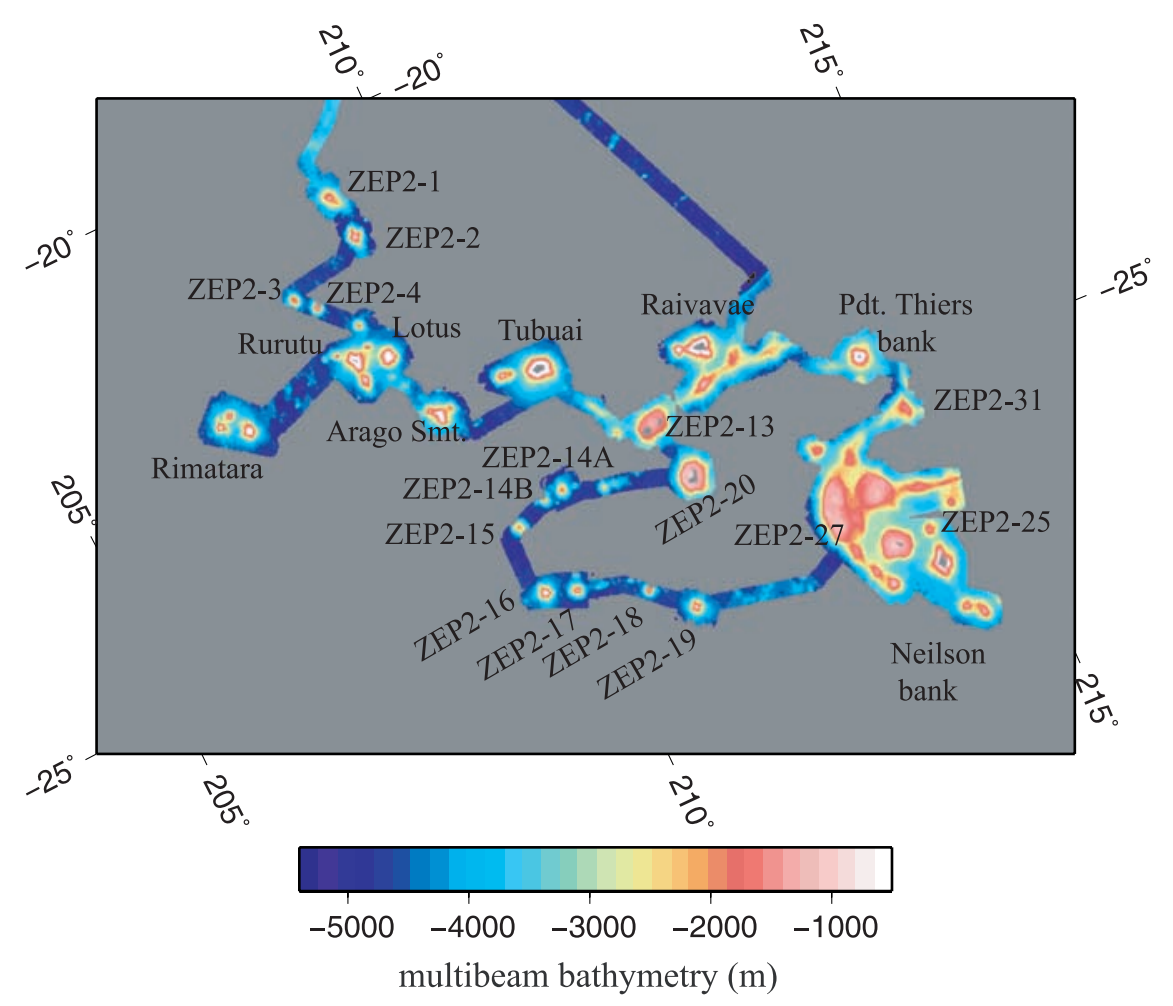

Figure 4. Multibeam coverage of the ZEPOLYF2 cruise [Bonneville, 2001]. The map is projected along the direction of the present Pacific plate motion $\left(\mathrm{N} 115^{\circ}\right)$.

seawater, and mantle, respectively (their values are given in Figure 2); $k$ is the two-dimensional wave number; $|k|$ is its modulus, and $g$ is the acceleration of gravity $\left(g=9.81 \mathrm{~m} \mathrm{~s}^{-2}\right)$.
[13] We then model the free-air gravity anomaly (FAA) corresponding to the model displayed in Figure 2. The FAA is the sum of the density contrasts occurring at the sea level where the volcanic load replaces the seawater and at the

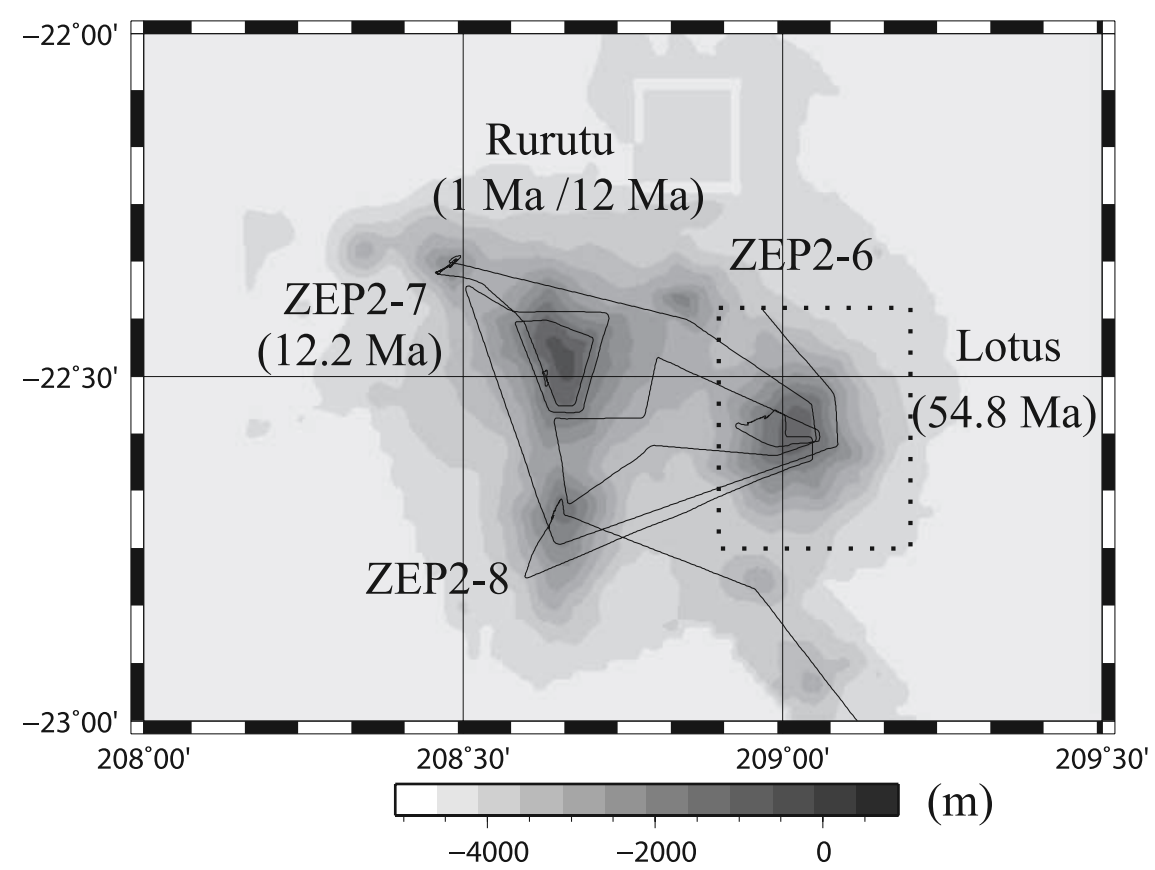

Figure 5. Bathymetry of Lotus and Rurutu. The mask used to separate the different volcanic stages is represented by a dashed line. The solid line represents the ship track. The volcanism ages are indicated in million years. 

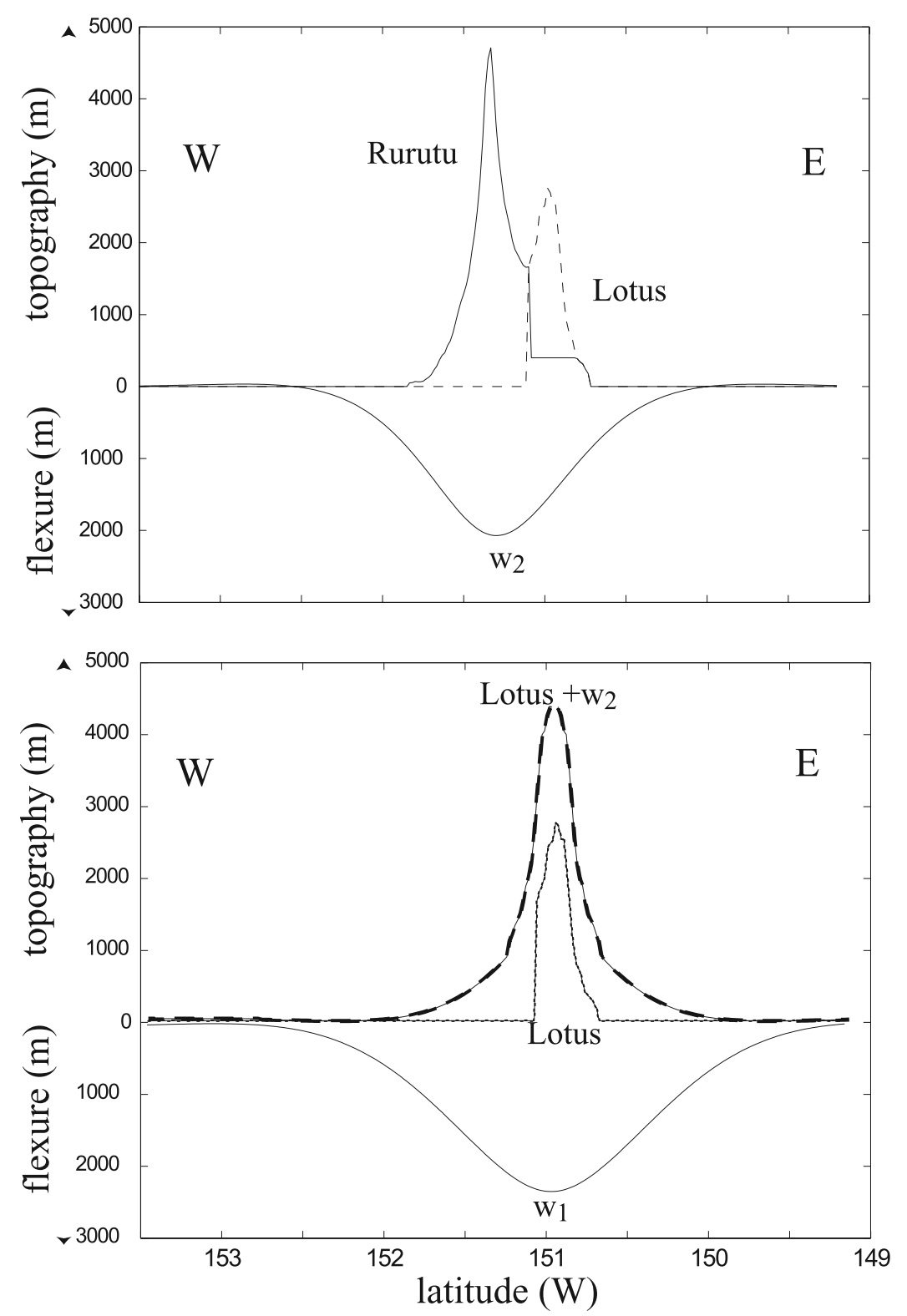

Figure 6. Reconstitution of the different volcanic stages that occurred on Lotus and Rurutu. Depth cross sections along latitude $-22.5^{\circ}$. (top) Decomposition of the present-day topographies and flexure due to the Rurutu loading. (bottom) The solid thin line represents the present-day topography of lotus, the dashed line represents Lotus' reconstituted topography, and the solid line represents the flexure due to its loading.

lower limit of the crust where, because of the flexure, the crust replaces a part of the mantle. It is computed in the wave number domain according to

$$
\begin{aligned}
G(k)= & +\frac{G\left(\rho_{v}-\rho_{w}\right)}{k g} e^{-2 \pi k d_{t c}} \sum_{n=1}^{m} \frac{k^{n-1}}{n !} H^{n}(k) \\
& -\frac{G\left(\rho_{v}-\rho_{w}\right)}{k g} e^{-2 \pi k d_{b c}} W(k)
\end{aligned}
$$

where $G(k)$ is the Fourier's transform of the FAA, $G$ is the gravity constant, $d_{t c}$ is the regional depth, $d_{b c}$ is the depth to the bottom of the crust (see Figure 2), $m$ is the development order, and $H^{n}(k)$ the Fourier's transform of $h^{n}(X)(h(X)$ being the volcano topography). In our studied region, the volcanoes are often small and sharp and a development till the sixth order $(m=6)$ is necessary.

[14] Finally, we compute a two-dimensional FAA for various values of $T_{e}$ and $\rho_{v}$. The preferred solution is that which minimized the root-mean-square misfit between observed FAA and computed FAA.

\section{Volcanism Overlapping}

[15] For some volcanoes, the determination of the elastic thickness is not so straightforward. When several volcanism stages overlap on a restricted area, or even on the same edifice, the different stages cannot be studied separately because of their mutual influence. Indeed, the last volca- 


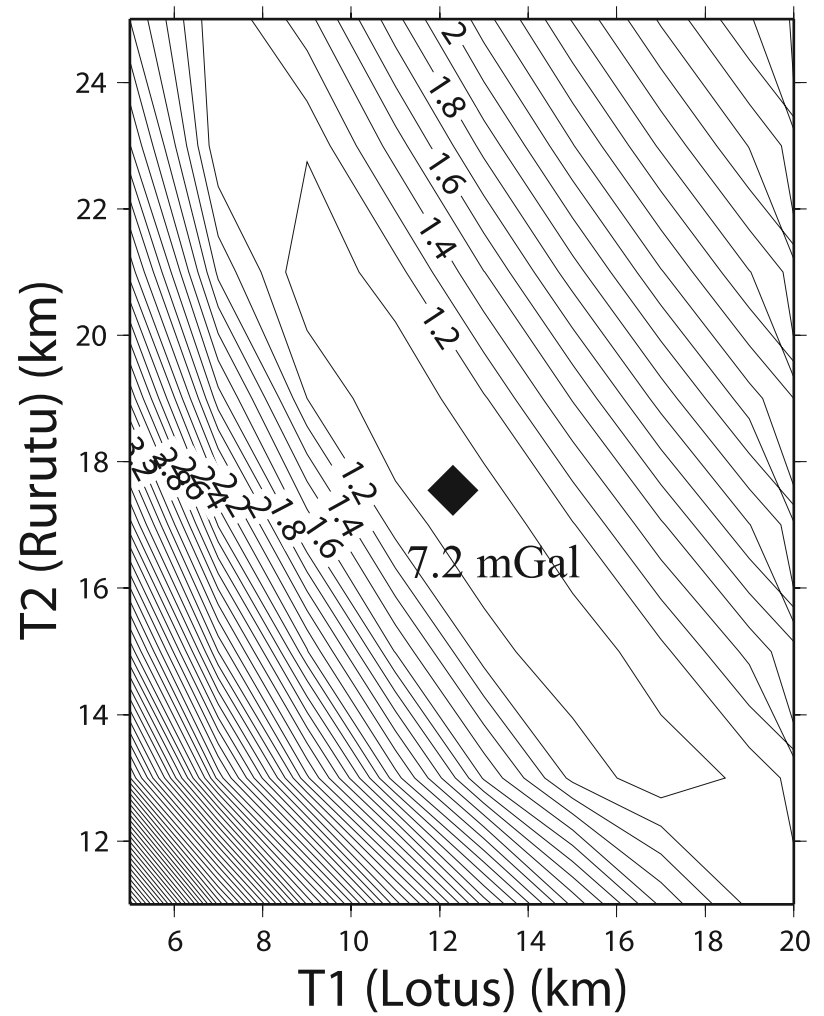

Figure 7. RMS computed for Rurutu and Lotus as a function of the elastic thicknesses relative to both the loadings. The isocontours are normalized by the minimal error $(7.2 \mathrm{mGal})$ found for $T_{1}=12.5 \mathrm{~km}$ and $T_{2}=18 \mathrm{~km}$.

nism stage has necessarily modified the topography built by the precedent stages and the flexure due to the loading of the anterior stages contributes to the observed gravity signal [McNutt et al., 1997]. It is then necessary to isolate the topographic contribution of each volcanic phase. Thus the different volcanism stages have to be studied together. When the observations (absolute ages, geochemistry or volcanoes morphology) are either insufficient or contradictory, we have to make assumptions on the loading chronology. This instance will be illustrated by the following examples. Most of the selected volcanoes are situated on the northern alignment, where the tectonic history is particularly complex.

\subsection{Rurutu and Lotus}

[16] Rurutu is an island whose summit reaches an altitude of $389 \mathrm{~m}$. Its morphology is elongated along the north-south direction. Two volcanism phases, at $1 \mathrm{Ma}$ and $12 \mathrm{Ma}$ are reported and it is surrounded by several seamounts (see Figure 5): (1) the ZEP2-6 edifice, northeast, is the smallest structure of the zone, (2) the seamount ZEP2-7 is a composite structure formed by a circular cone and a secondary cone; it is dated at 12.2 Ma., (3) the ZEP2-8 mount, south Rurutu is elongated along the north-south direction; its volume is twice the volume of the precedent structures, and (4) the Lotus mount, eastward of Rurutu is a "haut fond" shoal which summit reaches a $450 \mathrm{~m}$ depth; it is a very voluminous structure, covering a $10.2 \mathrm{~km} \times 10.2 \mathrm{~km}$ area.
Its guyot morphology stands it out from the other edifices. Its age is $54.8 \mathrm{Ma}$.

[17] At least three volcanism phases are then reported on this area: two phases at 1 and $12 \mathrm{My}$ responsible for the Rurutu and ZEP2-7 building and a much older phase, at 54.8 Ma, identified on Lotus. The last age agrees with the guyot morphology of this edifice. As we do not have any age for the ZEP2-6 and ZEP2-8 mounts, we will assume that they were built by one of the two phases which created Rurutu because the morphology of these seamounts is closer to the Rurutu one.

[18] If one considers what is chronologically happening, we can say that at first Lotus loads a $T_{1}$ thick lithosphere. Later, Rurutu loads the same lithosphere which has then a $T_{2}$ thickness. Rurutu loading bends the lithosphere, and push down a part of the Lotus topography. To reconstruct the initial topography of Lotus, we shall then add to its actual topography the flexure due to the Rurutu loading. Practically, we compute the flexure due to Rurutu and to the surrounding seamounts (ZEP2-6, ZEP2-7, and ZEP2-8) by masking Lotus (see dashed mask on Figure 5) and assuming a $T_{2}$ elastic thickness. We then obtain $\omega_{2}$. We add $\omega_{2}$ to the observed Lotus topography (taken this time inside the dashed mask in Figure 5) and obtain Louts' reconstituted topography. We use it to compute the flexure due to the Lotus loading $\left(\omega_{1}\right)$ on a $T_{1}$ thick lithosphere. This approach is illustrated on Figure 6.

[19] We then vary $T_{1}$ and $T_{2}$ and compute the FAA, assuming a volcanic density of $2800 \mathrm{~kg} \mathrm{~m}^{-3}$. We compare this modeled FAA to the FAA recorded along the ship track (solid line on Figure 5). On Figure 7, we show our results. We note that the RMS (the difference between the computed and the observed FAA at the root mean square meaning) is minimized for $T_{1}$ between 9 and $16 \mathrm{~km}$ and for $T_{2}$ between 12 and $21 \mathrm{~km}$. We consider that the $T_{1}=$ $9-16 \mathrm{~km}$ value is representative of the lithosphere at the time of the first loading $(t=54.8 \mathrm{Ma})$. However, as two volcanism stages ( 1 and $12 \mathrm{Ma}$ ) are reported on Rurutu, we cannot relate the $T_{2}=13-23 \mathrm{~km}$ to any of the volcanic episodes, since the present-day bathymetry and gravity are actually the result of the two phases.

\subsection{Raivavae}

[20] Overlapping volcanism also occurs on Raivavae and an elongated feature, ridge-type, situated a few kilometers south (Figure 8). Raivavae is an island which summit reaches $438 \mathrm{~m}$. West of the main edifice, lies a secondary volcano. South, a $3000 \mathrm{~m}$ deep basin adjoins a volcanic ridge orientated $\mathrm{N} 250^{\circ}$, which flat and ovoid summit is situated at a $2500 \mathrm{~m}$ depth. A $6.5 \mathrm{Ma}$ age is reported on the northeastern slope of Raivavae while a $33 \mathrm{Ma}$ age is found for the ridge. The RMS computation indicates a $11 \mathrm{~km}$ elastic thickness for the first loading (the ridge) and $18 \mathrm{~km}$ elastic thickness for the Raivavae loading.

[21] The radiometric ages available on Rurutu and Lotus and Rivavae and the southern ridge allowed us to reconstruct the history of the different loadings on these zones by isolating the volcanic phases. Such a scenario is repeated on other volcanoes groups, as as shown later. Nevertheless, in the following examples, the evidences allowing the separation of the volcanism phases are less 


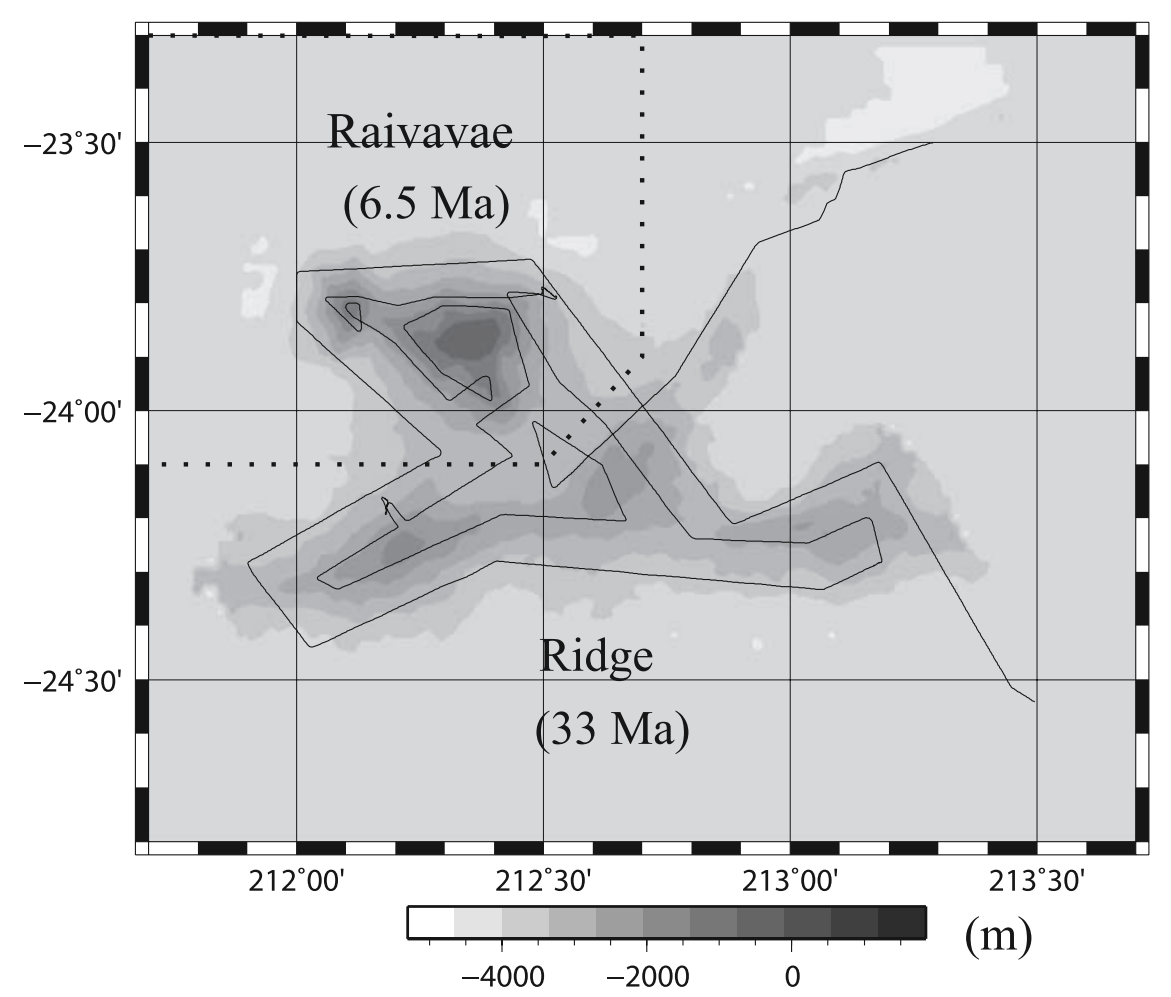

Figure 8. Bathymetry of Raivavae and a southern volcanic ridge. The solid line represents the ship track. The mask used to separate the different volcanic stages is represented by a dashed line. The volcanism ages are indicated in million years.

numerous and often contradictory. This leads us to make important assumptions on the loadings history. This is the case for Rimatara and the two surrounding seamounts, ZEP2-11 and ZEP2-12.

\subsection{Rimatara}

[22] The Rimatara island is the more voluminous edifice on the zone (Figure 9). Its basis diameter is about $30 \mathrm{~km}$.

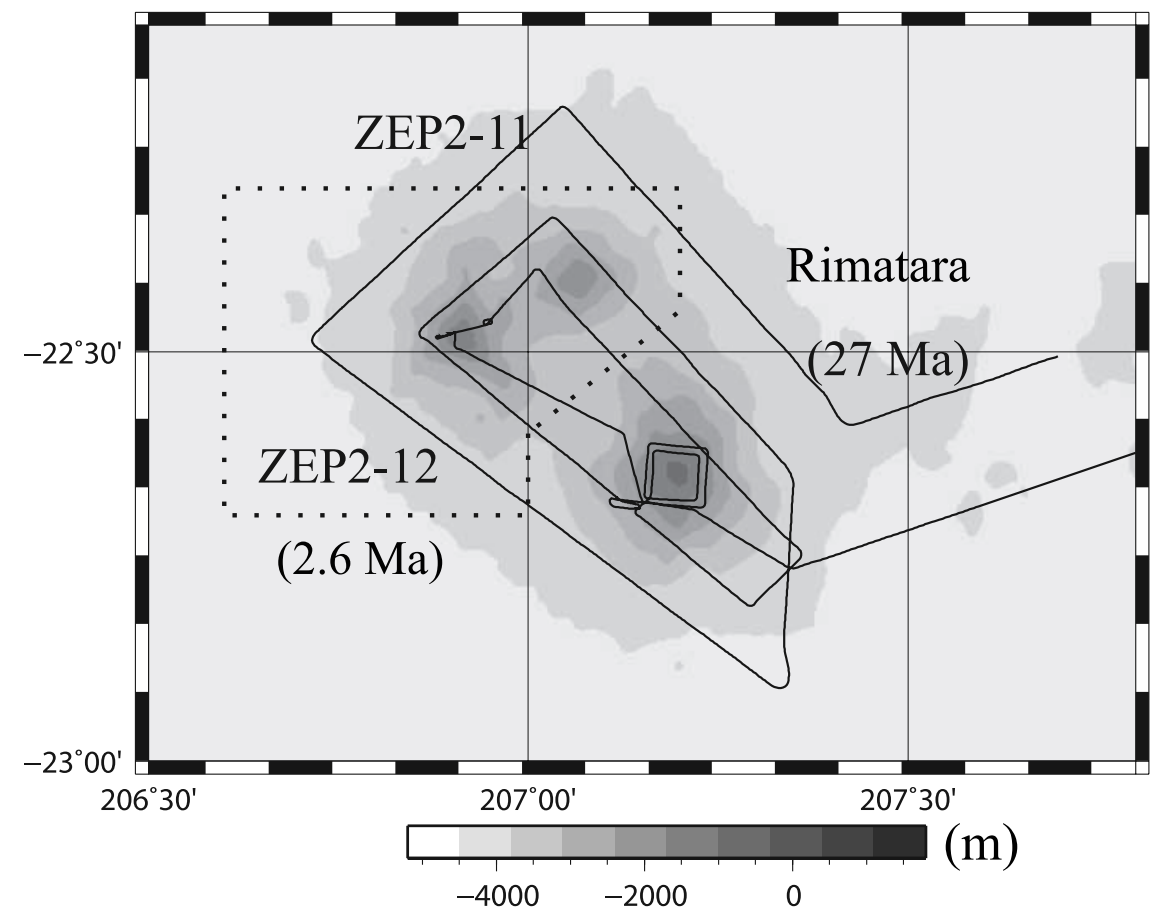

Figure 9. Bathymetry of Rimatara, ZEP2-11, and ZEP2-12. The solid line represents the ship track. The mask used to separate the different volcanic stages is represented by a dashed line. The volcanism ages are indicated in million years. 


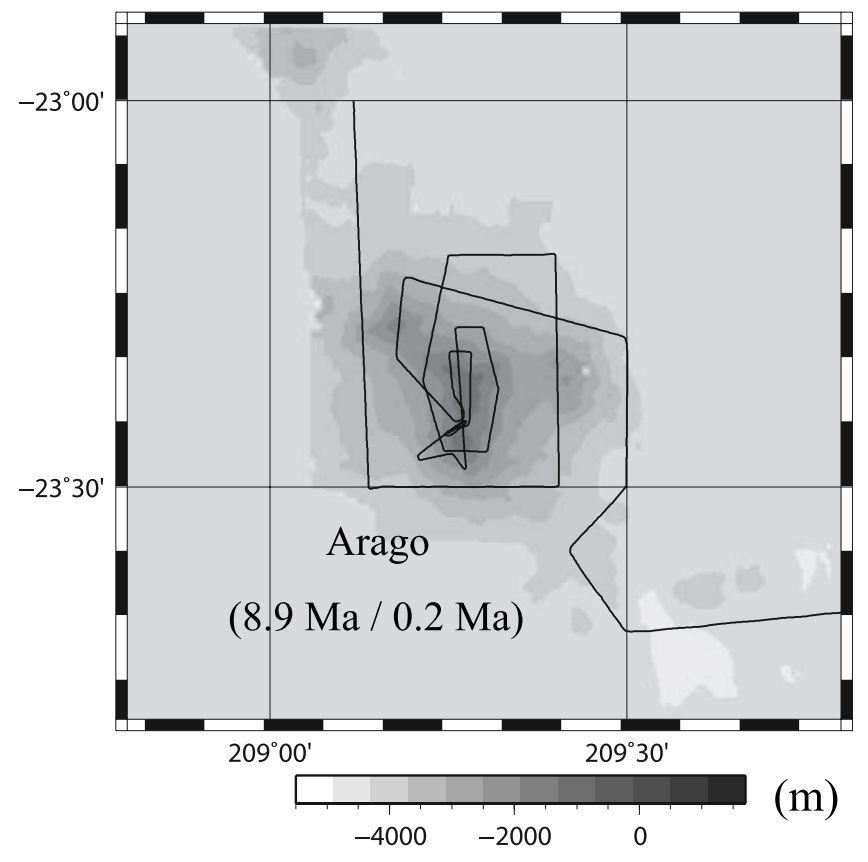

Figure 10. Bathymetry of Arago. The solid line represents the ship track. The volcanism ages are indicated in million years.

It is surrounded by two conic structures, rather circular: ZEP2-11 north and ZEP2-12 south. ZEP2-11, the smallest volcano and ZEP2-12 are aligned along the northeastsouthwest direction.

[23] Although two dates are available (2.6 Ma for ZEP2-12 [Bonneville et al., 2006] and 27 Ma for Rimatara [Turner and Jarrard, 1982]), several hypothesis have been checked on this area. Indeed, the $27 \mathrm{Ma}$ age reported on Rimatara has often been challenged. Moreover, its chemical signature relates it to the young Rurutu track which is now active at Arago [Bonneville et al., 2006]. By extrapolating its distance to Arago, one obtains a 2.4 Ma age for Rimatara. Besides, the magnetic signatures of the three volcanoes are very different. They indicate that several volcanism phases shifted in time are involved in the emplacement of ZEP2-11, ZEP2-12, and Rimatara. The indications are then contradictory. They do not allow a clear reconstruction of the chronology of the different loadings. All the possibilities should then be checked. We assumed, however, that ZEP2-11 and ZEP2-12 formed simultaneously. Indeed, these edifices are much smaller than Rimatara. Moreover, a preliminary study of the elastic thickness showed that the FAA over these volcanoes can be fit by a model assuming a simultaneous load.

[24] The first hypothesis assumes that Rimatara formed before ZEP2-11 and ZEP2-12, as indicated by the available dating. We studied this instance by decomposing the different volcanic phases, through the approach previously described for Rurutu and Lotus. We find that the lithosphere has a $25 \pm 7 \mathrm{~km}$ thickness when it is loaded by Rimatara. After this event, a lithospheric thinning occurs and when ZEP2-11 and ZEP2-12 form, the lithosphere is $10 \pm 3 \mathrm{~km}$ thick. The lithospheric thinning hypothesis is conceivable but this scenario must repeat elsewhere for it to be valid. Now, we do not find such a thinning neither for Rurutu and
Lotus nor for Raivavae and the southern ridge, where the indications are more numerous and less contradictory.

[25] We then consider another hypothesis. According to the second hypothesis, the mounts ZEP2-11 and ZEP2-12 load the lithosphere at first. This assumes that the $27 \mathrm{Ma}$ age reported on Rimatara is false, as indicated by its chemical signature that links Rimatara to the young Rurutu track. According to the logic of this second scenario, the $2.6 \mathrm{Ma}$ age reported on ZEP2-12 do not correspond to the first volcanic phase, but to a secondary volcanic phase which creates Rimatara (a $2.4 \mathrm{Ma}$ age is found for this volcano by extrapolating its distance to Arago). This secondary volcanic phase follows the weakness zone left in the lithosphere by the first loading and express itself again on ZEP2-12. We find that the lithosphere has a $9 \pm 3 \mathrm{~km}$ thickness at the time of the first loading and a $30 \pm 5 \mathrm{~km}$ thickness at the time of the second loading.

[26] We have shown how we decompose the volcanic stages occurring on a group of volcanoes. A supplementary difficulty is introduced when several volcanic phases are superimposed on the same volcano. In these cases, we have to make assumptions on the repartition of the observed bathymetry between the two volcanic stages: which part of the present-day topography is due to the first volcanic phase? Which one to the latest one? To describe this, we define a parameter $\alpha$ and assume that the volume relative to the first volcanic event is $\alpha \mathrm{h}(\mathrm{X})(\mathrm{h}(\mathrm{X})$ being the observed volcano topography). This approach is illustrated in more detail with the Arago example. It has been used to study the tectonic history of three cases (Arago, ZEP2-19, and Tubuai) which are discussed here below.

\subsection{Arago Seamount}

[27] Arago is a seamount whose summit is situated at $26.5 \mathrm{~m}$ depth (Figure 10). This edifice is elongated along the north-south direction and two volcanic episodes $(0.2$ and $8.7 \mathrm{Ma}$ ) are reported. A preliminary study which does not assume the overlapping of different volcanic stages indicate a $3 \mathrm{~km}$ elastic thickness. This low value may be explained by the fact that the last volcanic stage occurred only $0.2 \mathrm{Ma}$ ago. The lithosphere may then still be in the viscoelastic relaxation phase, as proposed by Lambeck [1981] to explain the observations on Rarotonga. As two volcanic stages separated by $8 \mathrm{Ma}$ occurred on this volcano, it is also likely that the simple elastic model applied to the present-day topography is not appropriate to describe the history of this seamount. It would then be useful to isolate the topography of each volcanic phase.

[28] The RMS between the observed and computed FAA is determined by varying the elastic thicknesses relative to both the loadings for different values of $\alpha$. In each case, the RMS shows several local minima among which it is difficult to choose. More precisely, the RMS generally displays a "minimal line" as we can see in Figure 11 where we have reported our results for $\alpha=0.1$ and $\alpha=$ 0.6 . For $\alpha=0.1$ we have some local minima for $T_{1}=2 \mathrm{~km} /$ $T_{2}=15 \mathrm{~km}, T_{1}=16 \mathrm{~km} / T_{2}=9 \mathrm{~km}$ and $T_{1}=22 \mathrm{~km} / T_{2}=6 \mathrm{~km}$. For $\alpha=0.6$, the minimal RMS line seems vertically shifted toward lower values of $T_{2}$. We have then local minima for $T_{1}=12 \mathrm{~km} / T_{2}=3 \mathrm{~km}, T_{1}=15 \mathrm{~km} / T_{2}=2 \mathrm{~km}$ and $T_{1}=21 \mathrm{~km} / T_{2}=1 \mathrm{~km}$. It is interesting to note that the $T_{1}=21-22 \mathrm{~km}$ minimum remains whatever the $\alpha$ value, 

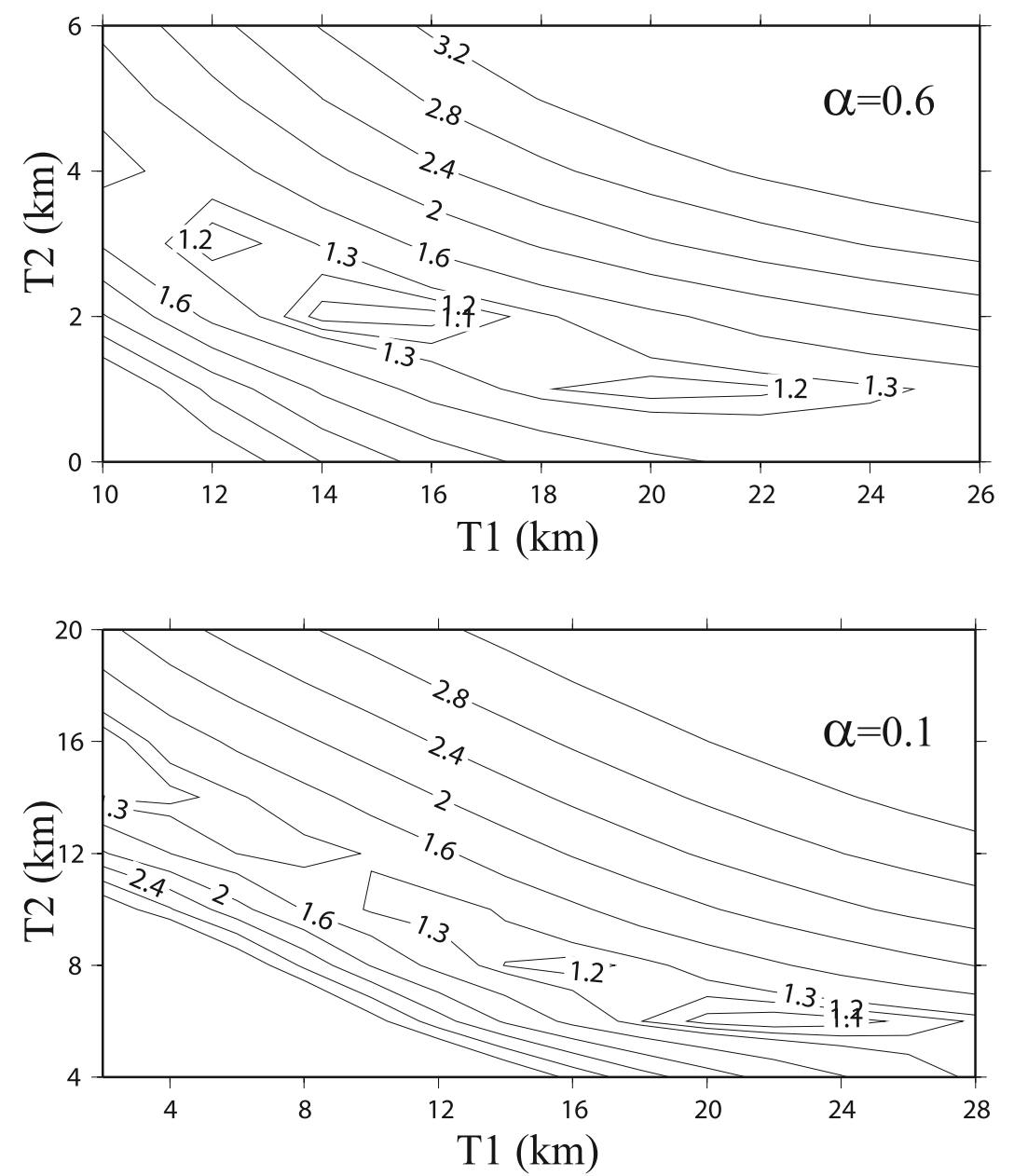

Figure 11. RMS computed for Arago as a function of the elastic thicknesses relative to both the loadings, assuming (bottom) $\alpha=0.1$ and (top) $\alpha=0.6$. The isocontours are normalized by the minimal error (3.7 and $5.5 \mathrm{mGal}$, respectively).

whereas its $T_{2}$ associated value is shifted downward when increasing the $\alpha$ value. One possible explanation for this observation is that the first loading really occurs on a $T_{e}=$ 21-22 km lithosphere whereas for the second loading the lithosphere may still be in the viscoelastic relaxation phase. This hypothesis is quite realist considering the young age of the second volcanic stage $(0.2 \mathrm{Ma})$. Another explanation may be that our volume estimate is not accurate enough to explain what it is really happening on this volcano. Our result for this edifice does not rule out the possibility of a lithospheric thinning since we cannot be sure of the volume repartition between the two volcanic stages, but show that other scenarios (as the loading of a normally thick lithosphere $8.7 \mathrm{Ma}$ ago and a second loading of a lithosphere which is still in the viscoelastic relaxation phase) are also possible.

\subsection{ZEP2-19}

[29] Such a superposition of two volcanic stages is also reported on the ZEP2-19 seamount, situated along the Macdonald track (see Figure 1 for location and Figure 12 for a more accurate view). Two samples dredged on this seamount have been analyzed. Only one sample has been dated at $8.8 \mathrm{Ma}$. The other one could not be dated but its geochemical characteristics are very different from the 8.8 Ma sample and they suggest that this sample belongs to another volcanic phase, which affected the region $20-$ $33 \mathrm{Ma}$ ago [Bonneville et al., 2006]. Then two volcanic stages, separated by 11-24 Ma are superimposed of this edifice. There again we compute the RMS between the observed and theoretical AAL by taking assumption on the volume associated with each phase. On the Figure 13, we show our results for $\alpha=0.9$. As in the Arago Seamount case, we can see that the difference between the observed and modeled AAL is minimized for several $T_{1} / T_{2}$ pairs. More precisely, a minimal RMS column seems to rise for $T_{1}=17 \mathrm{~km}$. The RMS is for example minimized for the $T_{1}=17 \pm 1 \mathrm{~km} / T_{2}=19 \pm 3 \mathrm{~km}$ pair. If we report these values in the diagram showing the elastic thickness as a function of the age of the lithosphere at the time of loading (dots in Figure 18), we can see that they describe a normal thermal structure of the lithosphere at the time of both the loadings. These values are not unique since we take strong hypothesis on the volume repartition between the two volcanic phases and we do not have any way to 


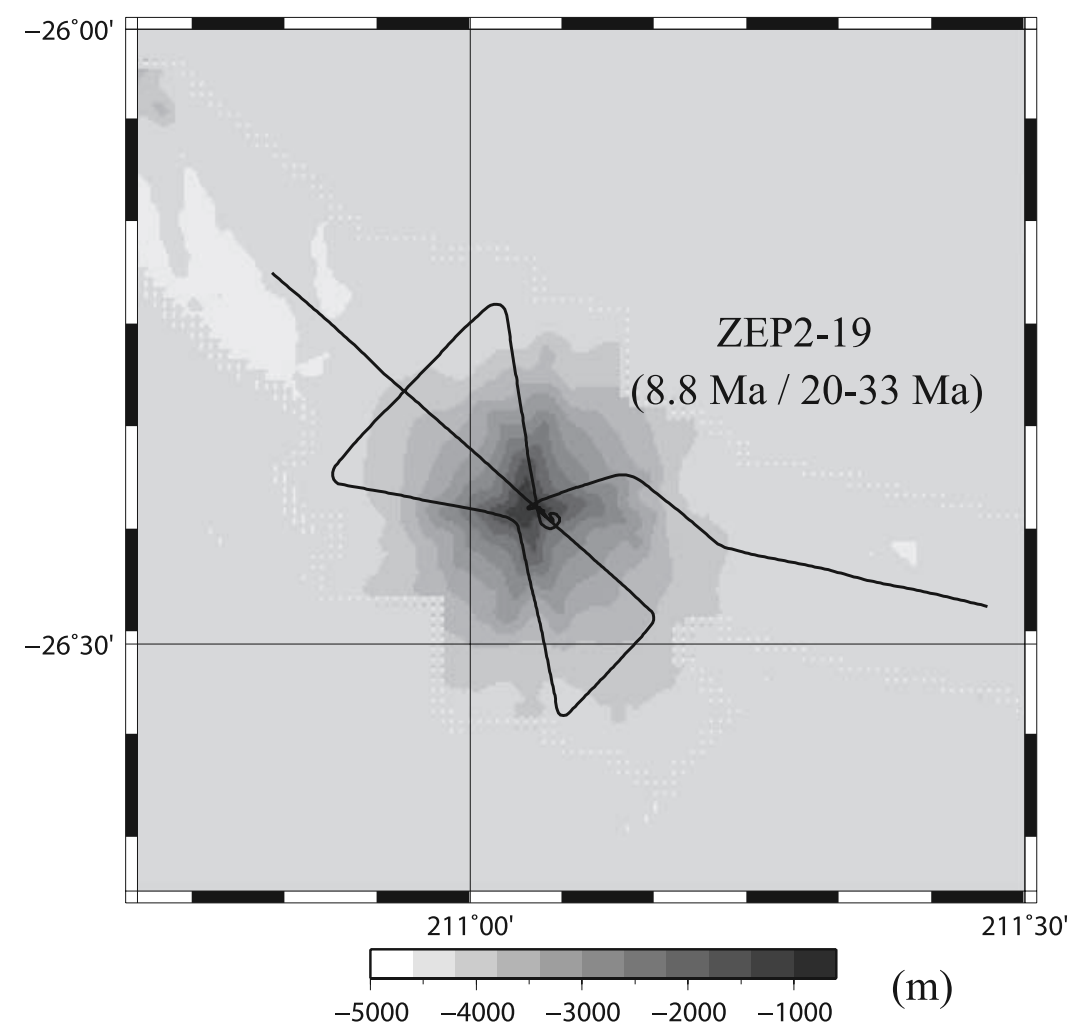

Figure 12. Bathymetry of the ZEP2-19 seamount. The black line represents the ship track.

assess their reliability. However, they show that it is possible that both the volcanism stages concerning this volcano (20-33 Ma and 8.8 Ma) may have occurred on a normal lithosphere.

\subsection{Tubuai}

[30] The proximity of Tubuai and ZEP2-10 leads us to associate their history. Tubuai is an island which maximal amplitude reaches $422 \mathrm{~m}$ (see Figure 14). A $8.8 \mathrm{Ma}$ age is reported on that island. ZEP2-10 is a volcano, situated northwest and elongated along the $\mathrm{N} 100^{\circ}$ direction. Its flat summit, $5.6 \mathrm{~km} \times 4.6 \mathrm{~km}$ in extension lies at a $1000 \mathrm{~km}$ depth.

[31] For these volcanoes, he have checked the hypothesis that Tubuai loads the lithosphere at first. This one has then a $4 \mathrm{~km}$ thickness. It then thickens and reaches a $6.5 \mathrm{~km}$ thickness when it is load by ZEP2-10. If one suppose that ZEPP2-10 loads the lithosphere at first the lithospheric thicknesses are $16 \mathrm{~km}$ for the first loading and $8 \mathrm{~km}$ for the second loading.

[32] Although only one age of $8.8 \mathrm{Ma}$ is available for Tubuai, we cannot rule out the hypothesis that this volcano is emplaced on an older edifice. It is the case for most of the surrounding volcanoes: two ages at 6.5 and $33 \mathrm{Ma}$ are reported on Raivavae and the southern ridge which are separated by less than $50 \mathrm{~km}$ and two volcanic stages at 0.2 and 8.7 Ma are reported on Arago. Moreover, the magnetism shows at least four dipoles on Tubuai [Bonneville, 2001], which indicates a complex geological history. We have then also checked the hypothesis that Tubuai was built by two volcanic stages.

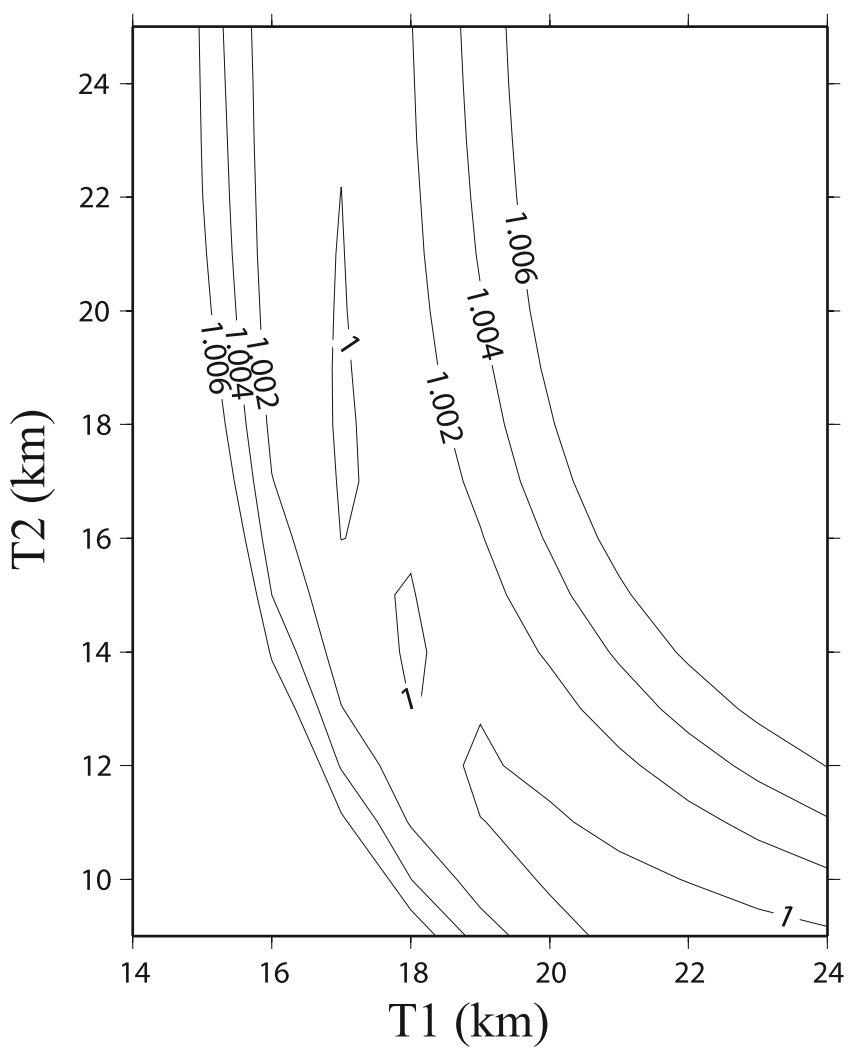

Figure 13. RMS computed for ZEP2-19 as a function of the elastic thicknesses relative to both the loadings, assuming $\alpha=0.9$ (see text). The isocontours are normalized by the minimal error $(6.2 \mathrm{mGal})$. 


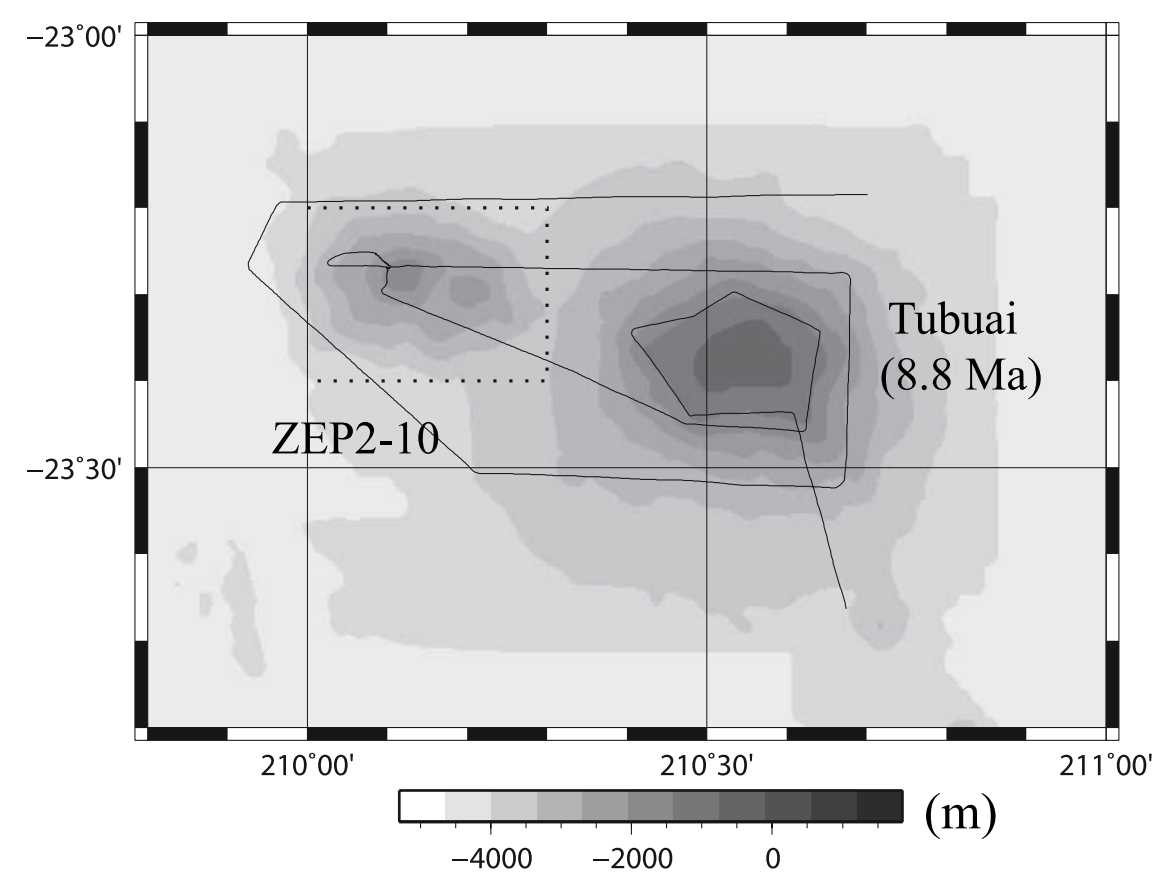

Figure 14. Bathymetry of Tubuai and ZEP2-10. The mask used to separate the different volcanic stages is represented by a dashed line. The solid line represents the ship track. The volcanism age is indicated in million years.

[33] We have here fewer indications than in the precedent cases. If we assume that the $8.8 \mathrm{Ma}$ age reported on Tubuai is relative to the oldest volcanic stage (which is the more probable case since dredges sample most of the time products from the latest volcanic phases) we do not know how old was the lithosphere during the first loading. There again, we make assumption of the volume fraction created by the different volcanic stages. The RMS found for $\alpha=0.2$ (Figure 15) shows a local minimum for $T_{1}=$ $11 \mathrm{~km} / T_{2}=13 \mathrm{~km}$ but also for $T_{1}=14 \mathrm{~km} / T_{2}=11 \mathrm{~km}$ and $T_{1}=9 \mathrm{~km} / T_{2}=18 \mathrm{~km}$. We do not have enough indications to know which minimum to prefer. Moreover, other solutions are introduced when we vary $\alpha$. We then cannot precisely determine the elastic thickness at the moment of Tubuai loading but our results show that it is quite possible that Tubuai loaded a lithosphere of normal thickness considering its age at the time of loading.

[34] We have shown how we reconstructed the topography relative to each volcanic event when several volcanism stages

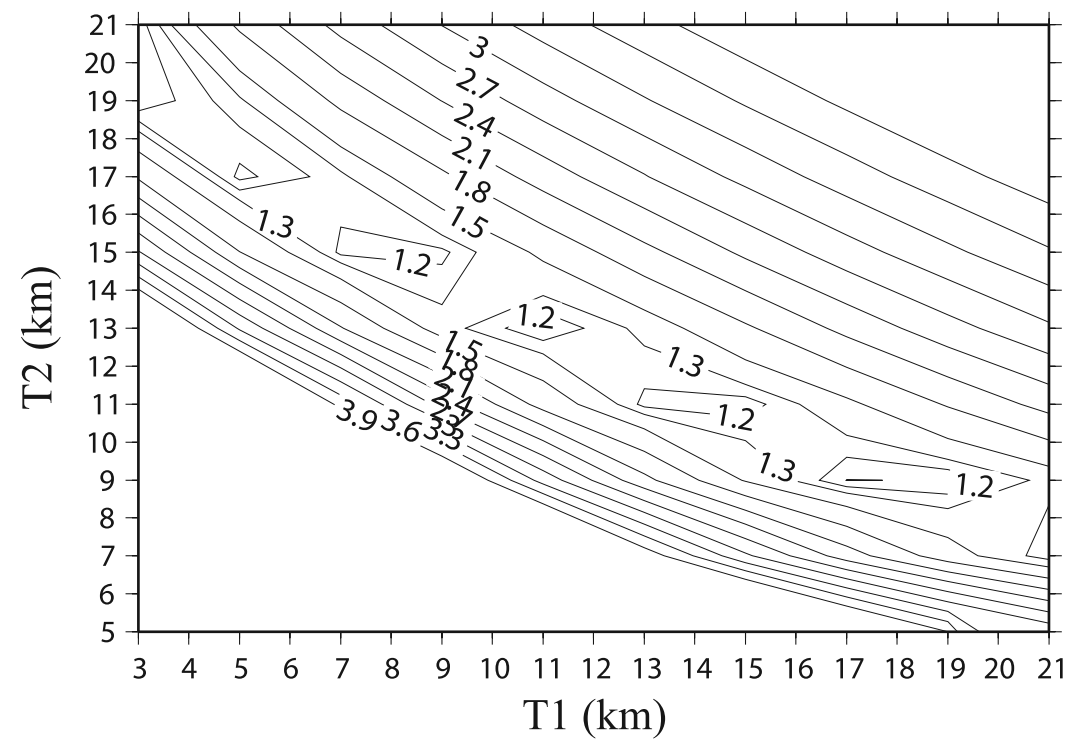

Figure 15. RMS computed for Tubuai assuming that it has been formed by two volcanic phases which volume ratio is $\alpha=0.2$ (see text). 
Table 1. Elastic Thickness and Density of the Volcanic Loads

\begin{tabular}{|c|c|c|c|}
\hline Seamount or Island & Lat/Lon & $T_{e}(\mathrm{~km})$ & $\rho_{v}\left(\mathrm{~kg} \mathrm{~m}^{-3}\right)$ \\
\hline ZEP2-1 & $\mathrm{S} 20^{\circ} 50 / \mathrm{W} 150^{\circ} 50$ & $2 \pm 1$ & $2700 \pm 50$ \\
\hline ZEP2-2 & $\mathrm{S} 21^{\circ} 15 / \mathrm{W} 150^{\circ} 45$ & $2 \pm 1$ & $2700 \pm 50$ \\
\hline ZEP2-3 & $\mathrm{S} 21^{\circ} 38 / \mathrm{W} 151^{\circ} 40$ & $2.5 \pm 1$ & $2700 \pm 50$ \\
\hline ZEP2-4 & $\mathrm{S} 21^{\circ} 48 / \mathrm{W} 151^{\circ} 29$ & $2.5 \pm 1$ & $2700 \pm 50$ \\
\hline ZEP2-6 ${ }^{\mathrm{a}}$ & $\mathrm{S} 22^{\circ} 22 / \mathrm{W} 151^{\circ} 10$ & 18. \pm 5 & 2750 \\
\hline $\mathrm{ZEP} 2-7^{\mathrm{a}}$ & $\mathrm{S} 22^{\circ} 03 / \mathrm{W} 151^{\circ} 31$ & 18. \pm 5 & 2750 \\
\hline ZEP2- $8^{\mathrm{a}}$ & $\mathrm{S} 22^{\circ} 41 / \mathrm{W} 151^{\circ} 21$ & $18 . \pm 5$ & 2750 \\
\hline Rurutu $^{a}$ & $\mathrm{~S} 22^{\circ} 28 / \mathrm{W} 151^{\circ} 21$ & 18. \pm 5 & 2750 \\
\hline Lotus $^{\mathrm{a}}$ & $\mathrm{S} 22^{\circ} 34.4 / \mathrm{W} 150^{\circ} 59$ & $12.5 \pm 3.5$ & 2750 \\
\hline $\operatorname{Arago}(0.2 \mathrm{Ma})^{\mathrm{a}}$ & $\mathrm{S} 23^{\circ} 26.4 / \mathrm{W} 150^{\circ} 43.8$ & $1 \pm 1$ & 2750 \\
\hline $\operatorname{Arago}(8.9 \mathrm{Ma})^{\mathrm{a}}$ & $\mathrm{S} 23^{\circ} 26.4 / \mathrm{W} 150^{\circ} 43.8$ & $21 \pm 1$ & 2750 \\
\hline ZEP2-10 & $\mathrm{S} 23^{\circ} 16.6 / \mathrm{W} 149^{\circ} 53$ & $6 \pm 1$ & $2700 \pm 50$ \\
\hline ZEP2-11 ${ }^{\mathrm{a}}$ & $\mathrm{S} 22^{\circ} 25 / \mathrm{W} 152^{\circ} 56$ & $9 \pm 3$ & 2750 \\
\hline ZEP2-12 ${ }^{\mathrm{a}}$ & $\mathrm{S} 20^{\circ} 30 / \mathrm{W} 153^{\circ} 05$ & $9 \pm 3$ & 2750 \\
\hline Rimatara $^{a}$ & $\mathrm{~S} 22^{\circ} 38 / \mathrm{W} 152^{\circ} 49$ & $30 \pm 5$ & 2750 \\
\hline ZEP2-13 & $\mathrm{S} 24^{\circ} 25 / \mathrm{W} 148^{\circ} 30$ & $5 \pm 1$ & $2750 \pm 50$ \\
\hline Raivavae $^{\mathrm{a}}$ & $\mathrm{S} 23^{\circ} 52 / \mathrm{W} 147^{\circ} 40$ & $18 \pm 4$ & 2750 \\
\hline Raivavae/ridge $\mathrm{a}^{\mathrm{a}}$ & $\mathrm{S} 23^{\circ} 52 / \mathrm{W} 147^{\circ} 40$ & $11 \pm 2$ & 2750 \\
\hline ZEP2-14 & $\mathrm{S} 24^{\circ} 39 / \mathrm{W} 149^{\circ} 48.5$ & $7 \pm 2$ & $2700 \pm 50$ \\
\hline ZEP2-15 & $\mathrm{S} 24^{\circ} 49.5 / \mathrm{W} 150^{\circ} 26$ & $4 \pm 2$ & $2700 \pm 50$ \\
\hline ZEP2-16 & $\mathrm{S} 25^{\circ} 34.6 / \mathrm{W} 150^{\circ} 30$ & $8 \pm 2$ & $2750 \pm 50$ \\
\hline ZEP2-17 & $\mathrm{S} 25^{\circ} 42 / \mathrm{W} 150^{\circ} 09$ & $5 \pm 1$ & $2750 \pm 50$ \\
\hline ZEP2-18 & $\mathrm{S} 26^{\circ} 01.5 / \mathrm{W} 149^{\circ} 23$ & $10 \pm 3$ & $2800 \pm 50$ \\
\hline ZEP2-19 & $\mathrm{S} 26^{\circ} 23.2 / \mathrm{W} 148^{\circ} 57$ & see text & \\
\hline ZEP2-20 & $\mathrm{S} 25^{\circ} 06 / \mathrm{W} 148^{\circ} 22$ & $7 \pm 1$ & $2700 \pm 50$ \\
\hline ZEP2-25 & $\mathrm{S} 26^{\circ} 26.8 / \mathrm{W} 145^{\circ} 40$ & $6 \pm 2$ & $2650 \pm 50$ \\
\hline ZEP2-27 & $\mathrm{S} 26^{\circ} 13.6 / \mathrm{W} 146^{\circ} 59.2$ & $6 \pm 2$ & $2700 \pm 50$ \\
\hline Neilson Bank & $\mathrm{S} 27^{\circ} 03 / \mathrm{W} 146^{\circ} 02$ & $3 \pm 2$ & $2700 \pm 50$ \\
\hline ZEP2-31 & $\mathrm{S} 25^{\circ} 22.3 / \mathrm{W} 145^{\circ} 42.7$ & $6 \pm 2$ & $2700 \pm 50$ \\
\hline President Thiers Bank & $\mathrm{S} 24^{\circ} 40 / \mathrm{W} 145^{\circ} 55$ & $6 \pm 6$ & $2700 \pm 50$ \\
\hline
\end{tabular}

${ }^{\mathrm{a}}$ Volcanoes for which we decomposed the different volcanic stages.

overlap on the same volcano or volcanoes group. This decomposition is necessary to compute the $T_{e}$ representative of the lithospheric state at the time of loading. We widely discussed the hypothesis on which we based our scenarios which lead to an estimation of the results accuracy. We will now interpret the results.

\section{Results and Discussion}

[35] Our results are summarized in Table 1 and displayed on Figure 16. There is no clear pattern in the spatial variations of $T_{e}$. To the north, $T_{e}$ values fall between 2 and $30 \mathrm{~km}$. To the south between 3 and $19 \mathrm{~km}$.

[36] We have reported our results for the dated volcanoes on the diagram showing the elastic thickness versus age of the lithosphere at the time of loading. We have split them into three groups: northern alignment, southern alignment and isolated volcanoes. The elastic thicknesses are theoretically situated between the 300 and $600^{\circ} \mathrm{C}$ isotherms (reported on Figures 17, 18, 20) for ages less that $70 \mathrm{Ma}$ [Parsons and Sclater, 1977]. On this figure, we have also reported the empirical law found by Calmant and Cazenave [1987] (2.7 $\sqrt{t}$, dashed line). We will now see how our results can be interpreted for each of the three groups and how they differ from the values previously found on this zone.

\subsection{Isolated Volcanoes}

[37] The isolated volcanoes are found throughout the study area. The corresponding values of $T_{e}$ beneath them fall above the $300^{\circ} \mathrm{C}$ isotherm (see Figure 17). One can note that all these volcanoes are the oldest of the zone (age > $20 \mathrm{Ma}$ ) and most of them have guyot's morphologies (the Neilson Bank, ZEP2-20, ZEP2-26, and ZEP2-31 seamounts). One possible origin could be linked to the presence of the thick layer of carbonate reefs constructed on top of the guyots that could represent in some cases a real important volume. This limestone platform has a lower density than

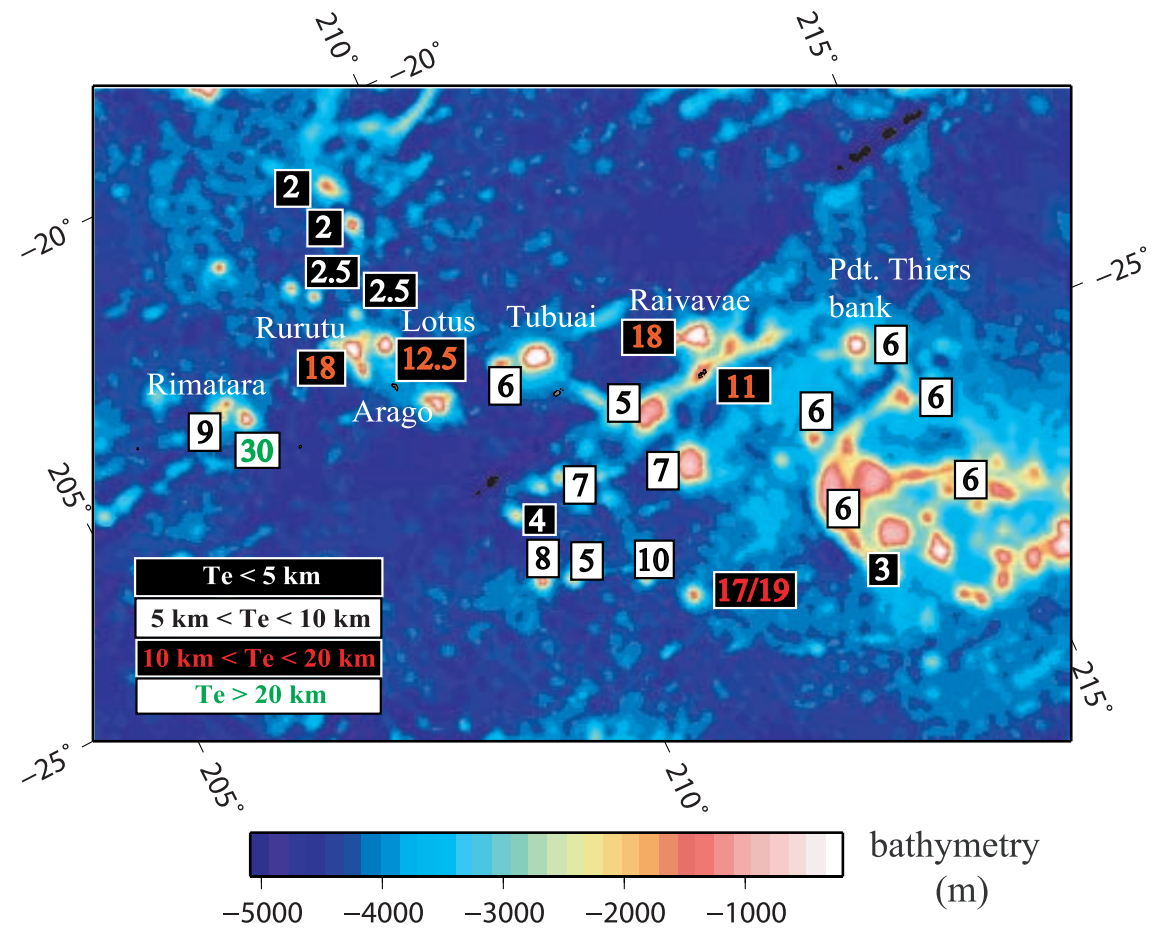

Figure 16. Elastic thickness obtained in this study. The young and old Rurutu tracks and the Macdonald track are also reported. 


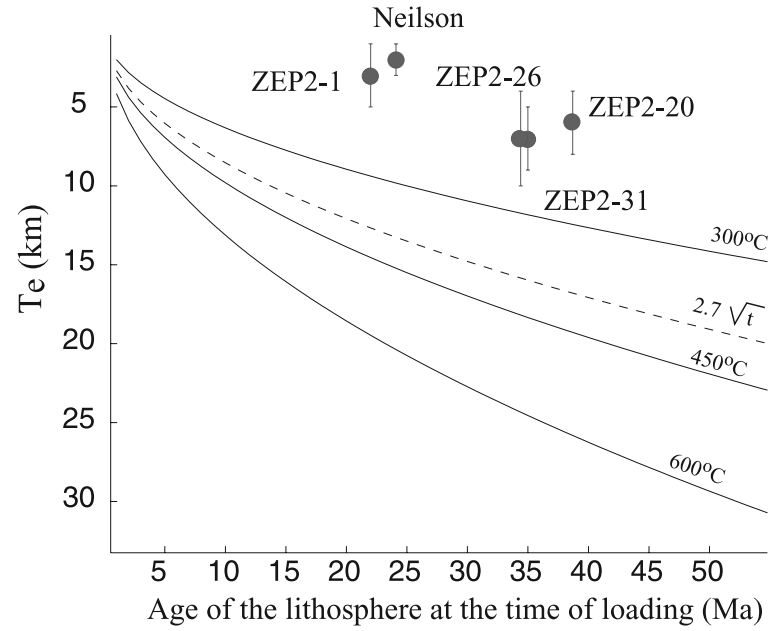

Figure 17. Elastic thickness as a function of the age of the lithosphere at the time of loading for the isolated volcanoes. We have also reported the theoretical curves (the 300, 450, and $600^{\circ} \mathrm{C}$ isotherms) as well as the empirical curve of Calmant and Cazenave [1987] $(2.7 \sqrt{t})$.

the basaltic edifice but have been emplaced long after the main volcanic stage and if its thickness is large enough it could have induced a secondary flexure leading to an underestimation of $T_{e}$. This is really speculative but in the absence of more information on the internal structure of these guyots, it is hardly difficult to reconstruct the initial topography of the volcano per se and thus make a better accurate determination of $T_{e}$.

\subsection{Southern Alignment}

[38] For the southern alignment, the ZEP2-14A, ZEP214B, ZEP2-16, ZEP2-17, and ZEP2-18 seamounts are characterized by $T_{e}$ values around $8 \mathrm{~km}$. Since these edifices are not dated we cannot determine the state of the lithosphere at the moment they loaded it. Only one age is available in the vicinity: 8.9 Ma reported for ZEP2-19 seamount. However, the chemical analyses show that this volcanism phase is superimposed on a much older one (20$33 \mathrm{Ma}$ ) [Bonneville et al., 2006]. As two phases are superimposed on the same volcano, we apply the decomposition method previously described and show that for some parameters (as $\alpha=0.9$ ) we find "normal" values of the elastic thickness of the lithosphere (Figure 18).

[39] These results agree well with the results of McNutt et al. [1997] and Jordahl et al. [2004], who show that the Macdonald seamount has loaded a lithosphere characterized by a normal elastic thickness. To obtain these values, the authors decomposed the different volcanic stages which occurred on the Macdonald (0-5 Ma), Ngatemato (28$345 \mathrm{Ma}$ ), and Taukina (20 Ma) chains. The main difference between their studies is that McNutt et al. [1997] perform one-dimensional flexural modeling whereas [Jordahl et al., 2004] use a 2-D modeling. Jordahl et al. [2004] report a 15-20 km elastic thickness and McNutt et al. [1997] report a $15 \mathrm{~km}$ elastic thickness beneath the Macdonald seamount It is interesting to note that the previous studies which do not take into account the volcanism overlapping always underestimate the effective elastic thickness [Calmant and Cazenave, 1987; Sichoix, 1997].

[40] Calmant and Cazenave [1987] and Sichoix [1997] also report a thinned lithosphere beneath Mangaia, Rapa and Marotiri. However, the anomalously low value reported for Marotiri can also be explained by volcanism overlapping since two very different ages (39.6 and $3.75 \mathrm{Ma}$ ) have been reported for this volcano [McNutt et al., 1997]. Unfortunately, the volcanoes morphology is too complicate to allow an accurate separation between the different volcanic stages and thus $T_{e}$ cannot be computed using two separate loading episodes without additional information.

[41] On Rapa Island, only one volcanic phase has been dated (5.1 Ma); however, the anomalously low $T_{e}$ seems also likely to be due to overlapping volcanism. Rapa is located less than $110 \mathrm{~km}$ away from Marotiri where such overlapping occurs. Besides, McNutt et al. [1997] report that both young $(0-5 \mathrm{Ma})$ and old (29-32 Ma) ages are generally found for rocks dredged from the deep flanks of the Macdonald line. There again, the morphology of this zone is quite complicated and we do no have enough elements to correctly isolate the different volcanic stages.

[42] The anomalously low $T_{e}$ reported by Sichoix [1997] at Mangaia could be attributed either to the different volcanic phases superimposition or to the quality of the data used in this study. Sichoix [1997] results are indeed derived from single-beam bathymetry, and Filmer et al. [1993] already showed that the elastic thickness values obtained from single-beam bathymetry are systematically lower than the ones derived from multibeam bathymetry. Better data are required in this case for further interpretation at Mangaia.

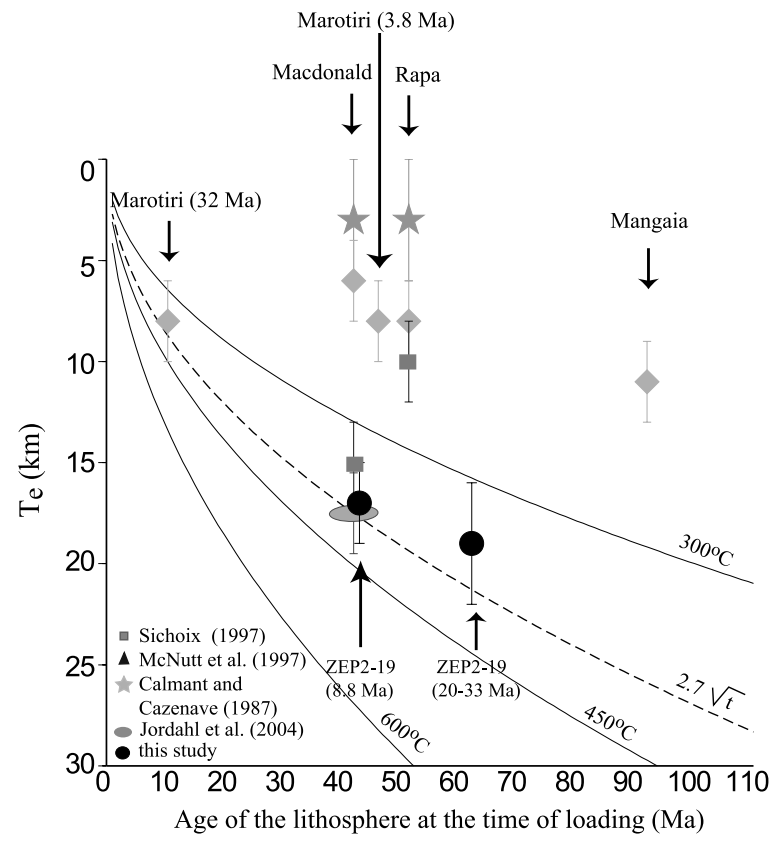

Figure 18. Elastic thickness as a function of the age of the lithosphere at the time of loading for the southern alignment. Our results account for the volcanism overlapping. We also have reported the theoretical curves (the 300,450 and $600^{\circ} \mathrm{C}$ isotherms) as well as the empirical curve of Calmant and Cazenave [1987] $(2.7 \sqrt{t})$. 


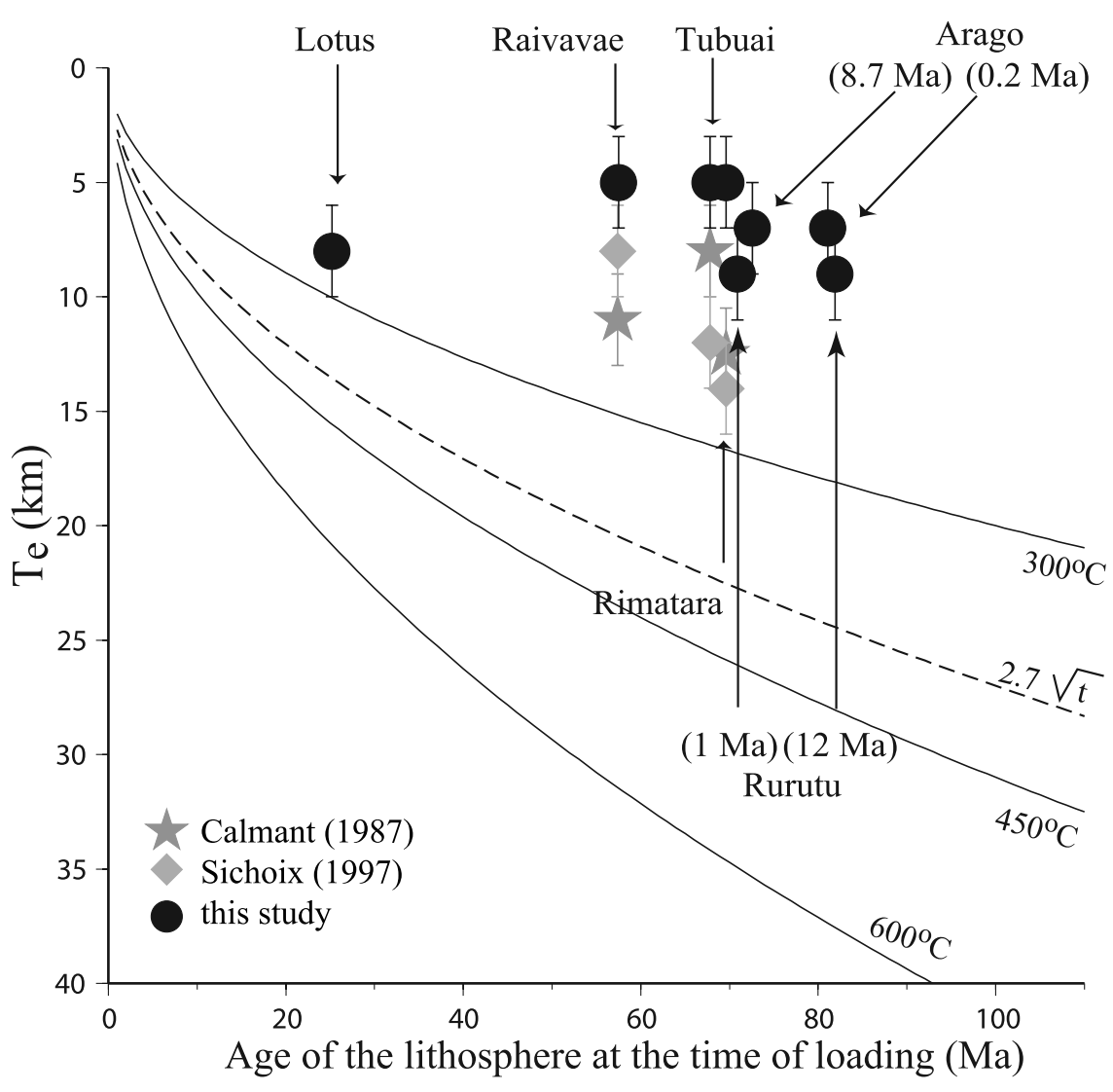

Figure 19. Elastic thickness as a function of the age of the lithosphere at the time of loading for the southern alignment. The results shown in this figure are obtained through a classical computation which do not account for the volcanism overlapping. We also have reported the theoretical curves (the 300,450 , and $600^{\circ} \mathrm{C}$ isotherms) as well as the empirical curve of Calmant and Cazenave [1987] $(2.7 \sqrt{t})$.

[43] The study of $T_{e}$ along the Macdonald track shows that the lithosphere is characterized by a normal elastic thickness considering its age at the time of loading when the different volcanism stages are isolated and when good quality data are used.

\subsection{Northern Alignment}

[44] For the two northern alignments, the overlapping situation is even more complex. The ages show indeed that several volcanic stages occurred on that region: the old and young Rurutu tracks and also a much older stage which built Lotus and (54.8 Ma) and ZEP2-1 (55.8 Ma). The elastic thicknesses found on this zone before our study indicate a thinned lithosphere (Figure 19). Most of the elastic thicknesses already published on this region come from the works of Sichoix [1997] and Calmant and Cazenave [1987], who did not use the decomposition within different volcanic stages.

[45] We wanted to know at first, which results we would have obtained with a similar study. In Figure 19, we represent our results obtained with the simple elastic model. Our values show a thinned lithosphere, as reported in the previous studies.

[46] As previously mentioned, the simple elastic model is not appropriate for the study of most of the volcanoes on the northern alignment. We have then tried to reconstruct the tectonic history relative to each edifice or edifices group by decomposing the different volcanic phases which occurred there. The tested scenarios are based on the indications provided by the ages, the isotopic analyses and the volcanoes morphology. In most of the cases, we have few insights and they are often contradictory. The most solid indications are provided at Rurutu and Lotus and Raivavae and the southern ridge since the available ages agree with the isotopic tendencies and the volcanoes morphology: Lotus is a $54.8 \mathrm{Ma}$ old guyot.

[47] Our results are displayed in Figure 20. By isolating the different volcanic stages, we find that the lithosphere has a normal elastic thickness (considering its age at the time of loading) at (1) Raivavae and the southern ridge, (2) Rimatara, (3) the 8.7 Ma volcanic stage at Arago, and (4) Lotus. We have not reported the elastic thickness beneath Rurutu since two volcanic stages (1 Ma, $12 \mathrm{Ma}$ ) occurred on this island. If reported in the $T_{e}$ versus age of the lithosphere graphic, the $T_{e}=13-23 \mathrm{~km}$ value is a normal considering the age of the lithosphere at the time of loading but this value is actually a combination of the effects of the two volcanic episodes.

[48] For Arago Seamount, we have reported one of the possible values found for the $8.7 \mathrm{Ma}$ stage. We think that for the youngest phase $(0.2 \mathrm{Ma})$ the lithosphere may still be in the viscoelastic relaxation phase.

[49] We have not reported the $T_{e}$ value of $18 \mathrm{~km}$ for Tubuai, because this value has required too many assump- 


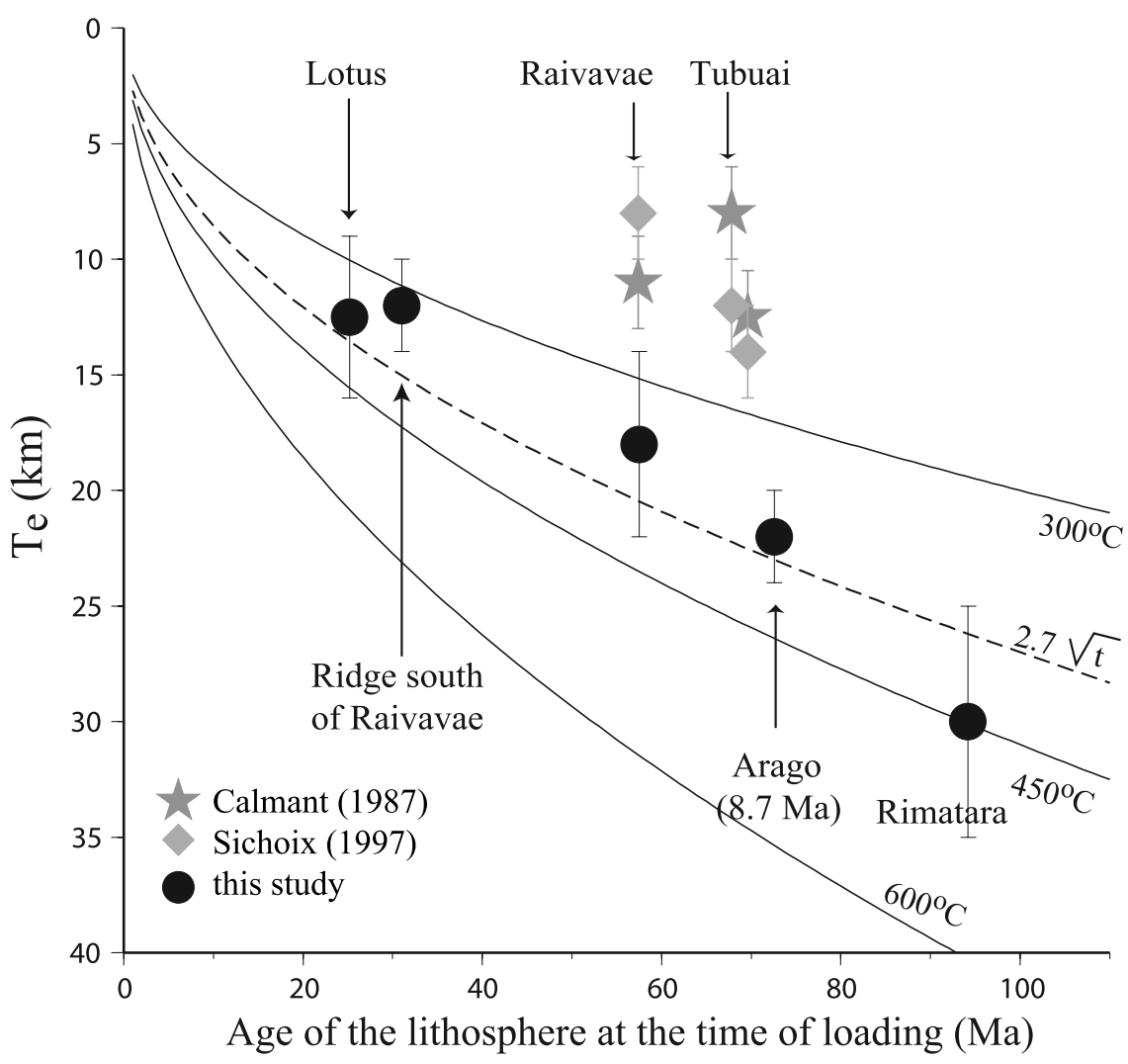

Figure 20. Elastic thickness as a function of the age of the lithosphere at the time of loading for the northern alignment. In this figure, our results account for the volcanism overlapping. We also have reported the theoretical curves (the 300,450 , and $600^{\circ} \mathrm{C}$ isotherms) as well as the empirical curve of Calmant and Cazenave [1987] $(2.7 \sqrt{t})$.

tions. However, it is interesting to note that this value would also describe a normal thickness of the lithosphere considering its age at the time of loading.

[50] Finding normal elastic thickness through the reconstruction of the history of the different loadings allows us to propose that there is no lithospheric thinning on that zone as previously reported. This study validates also the elastic model on a zone crossed by the Austral fracture zone and where the stresses have been modified by the succession of different volcanic stages. Moreover, the reconstruction managed for Rurutu and Lotus and for Raivavae and the southern ridge where the indications are reliable show that there is no thermal rejuvenation over this region. The lack of thermal rejuvenation is confirmed by the fact that no bathymetry or geoid anomalies are associated with this alignment [Adam et al., 2005].

\section{Conclusion}

[51] The emplacement of the Cook-Austral chains is complex and involves several volcanic stages which overlap sometimes on the same volcanoes (Rurutu, Arago, ZEP2-19, Marotiri). We tried to bring new information on the loading history of this chain by studying the variation of the elastic thickness of the lithosphere along the northern part of the Austral chain. We show that the elastic thickness of the lithosphere is abnormally low beneath the isolated volcanoes. These low values are partially due to the fact that the volume used in our model underestimates the initial volume which flexed the lithosphere and which have been eroded since the volcanoes emplacement.

[52] For both the southern and northern alignments, we show that the lithosphere may be characterized by normal elastic thickness if one correctly isolates the different volcanic stages occurring on this area. For the southern part of the chain we show that the two loadings stages of the ZEP2-19 Seamount (20-33 Ma and 8.9 Ma) may have occurred on a normal lithosphere. This result is in good agreement with the latest value obtained for the Macdonald through the decomposition of the different volcanic stages. The values obtained before this study (Marotiri, Rapa, Mangaia) may be biased because they have been obtained without taking into account such a volcanism overlapping or from single-beam bathymetry data. For the northern alignment, our results also indicate a normal lithosphere.

[53] As the Cook-Austral are the only hot spot chains of the South Pacific Superswell where abnormally low values of the effective elastic thickness of the lithosphere were subsisting, our results confirms that there is no thinning of the lithosphere associated with the South Pacific Superswell.

[54] Acknowledgments. This paper has been greatly improved thanks to the detailed comments of reviewers K. Jordahl and M. McNutt. The ZEPOLYF2 cruise was funded by the government of French 
Polynesia in the framework of the ZEPOLYF program. We also thank T. Fujiwara for a friendly review. This is IPGP contribution 2390.

\section{References}

Adam, C., V. Vidal, and A. Bonneville (2005), MiFil: A method to characterize seafloor swells with application to the south central Pacific, Geochem. Geophys. Geosyst., 6, Q01003, doi:10.1029/2004GC000814.

Barsczus, H., G. Guille, R. C. Maury, C. Chauvel, and H. Guillou (1994), Two magmatic sources at Rurutu Island (Austral Islands, French Polynesia) and the Austral "hotline", Eos Trans. AGU, 75(16), Spring Meet. Suppl., 323.

Bonneville, A. (2001), Rapport de fin de campagne ZEPOLYF2, technical report, Univ. de la Polynésie Fr., Papeete, Tahiti, French Polynesia.

Bonneville, A., R. Lesuave, L. Audin, V. Clouard, L. Dosso, P. Gillot, A. Hildenbrandt, P. Janey, and K. Jordahl (2002), Arago seamount: the missing hot spot found in the Austral islands, Geology, 1023-1026.

Bonneville, A., L. Dosso, and A. Hildenbrand (2006), Temporal evolution and geochemical variability of the South Pacific superplume activity, Earth Planet. Sci. Lett., 244, 251-269.

Calmant, S., and A. Cazenave (1986), The effective elastic lithosphere under the Cook Austral and Society Islands, Earth Planet. Sci. Lett. $77,187-202$

Calmant, S., and A. Cazenave (1987), Anomalous elastic thickness of the oceanic lithosphere in the south central Pacific, Nature, 328, 236-238.

Cazenave, A., B. Lago, K. Dominh, and K. Lambeck (1980), On the response of the oceanic lithosphere to sea-mount loads from GEOS3 satellite radar altimeter observations, Geophys. J. R. Astron. Soc., 63, $233-252$

Filmer, P., M. McNutt, and C. Wolfe (1993), Elastic thickness on the lithosphere in the Marquesas and Society islands, J. Geophys. Res., 98, $19,565-19,577$

Jordahl, K. A., M. K. McNutt, and D. W. Caress (2004), Multiple episodes of volcanism in the Southern Austral Islands: Flexural constraints from bathymetry, seismic reflection, and gravity data, J. Geophys. Res., 109, B06103, doi:10.1029/2003JB002885.

Lambeck, K. (1981), Flexure of the ocean lithosphere from island uplift bathymetry and geoid height observations: The Society Islands, Geophys. J. R. Astron. Soc., 67, 91-114.

Mayes, C., L. Lawver, and D. Sandwell (1990), Tectonic history and new isochron chart of the South Pacific, J. Geophys. Res., 95, 8543-8567.

McNutt, M. (1980), Implications of regional gravity for state of stress in the Earth's crust and upper mantle, J. Geophys. Res., 85, 6377-6397.
McNutt, M. (1984), Lithospheric flexure and thermal anomalies, J. Geophys. Res., 89, 11,180-11,194.

McNutt, M. (1998), Superswells, Rev. Geophys., 36, 211-244.

McNutt, M., and K. Fischer (1987), The South Pacific Superswell, in Seamounts, Islands, and Atolls, Geophys. Monogr. Ser., vol. 43, edited by B. H. Keating et al., pp. 25-34, AGU, Washington, D. C.

McNutt, M., and H. Menard (1978), Lithospheric flexure and uplifted atolls, J. Geophys. Res., 83, 1206-1212.

McNutt, M., D. Caress, J. Reynolds, K. Jordhal, and R. Duncan (1997), Failure of plume theory to explain midplate volcanism in the southern Austral Islands, Nature, 389, 479-482.

Parsons, B., and J. Sclater (1977), An analysis of the variation of ocean floor bathymetry and heat flow with age, J. Geophys. Res., 82, 803-827.

Sichoix, L. (1997), Le volcanisme de la Polynésie française: Caractérisation des points chauds et du Superbombement à partir d'une nouvelle synthèse bathymétrique, Ph.D. thesis, 297 pp., Univ. Fr. du Pac., Papeete, Tahiti.

Turner, D., and R. Jarrard (1982), K-Ar dating of the Cook-Austral island chain: A test of the hot-spot hypothesis, J. Volcanol. Geotherm. Res., 12, $187-220$

Watts, A. B. (1978), An analysis of isostasy in the world's oceans: 1. Hawaiian-Emperor Seamount Chain, J. Geophys. Res., 83, 5989-6004. Watts, A. B., and N. M. Ribe (1984), On geoid heights and flexure of the lithosphere at seamounts, J. Geophys. Res., 89, 11,152-11,170.

Watts, A. B., J. R. Cochran, and G. Selzer (1975), Gravity anomalies and flexure of the lithosphere: A three-dimensional study of the Great Meteor Seamount, northeast Atlantic, J. Geophys. Res., 80(11), 1391-1399.

Watts, A. B., J. H. Bodine, and M. S. Steckler (1980), Observations of flexure and the state of stress in the oceanic lithosphere, J. Geophys. Res., 85(11), 6369-6376.

Wessel, P., and W. Smith (1991), Free software helps map and display data, Eos Trans., 72, 441.

Young, R. Y., and I. A. Hill (1986), An estimate of the effective elastic thickness of the Cape Verde Rise, J. Geophys. Res., 91, 4854-4866.

C. Adam, Institute for Research on Earth Evolution, Japan Agency for Marine-Earth Science and Technology, 2-15 Natsushima-cho, Yokosuka, 237-0061, Japan. (adam@jamstec.go.jp)

A. Bonneville, Laboratoire de Géosciences Marines, Institut de Physique du Globe de Paris, CNRS, 4 place Jussieu, F-75252 Paris, France. 